\title{
O “novo sindicalismo" pela ótica dos estudos do trabalho
}

\author{
Mario Henrique Ladosky \\ Roberto Véras de Oliveira*
}

Resumo: Este artigo pretende realizar um balanço crítico e em perspectiva histórica dos estudos realizados no país a respeito do fenômeno amplamente reconhecido por "novo sindicalismo", o qual teve suas origens situadas na passagem dos anos 1970 aos 1980 e cujo epicentro foram as greves operárias do ABC paulista ocorridas nesse período. Tem como objetivo identificar as principais linhas de interpretação que se constituíram até os dias atuais, sobretudo, nos campos das Ciências Sociais e da História Social. A abordagem tem como eixo interpretativo as interfaces entre a construção prático-discursiva associada ao "novo sindicalismo" e a questão democrática brasileira.

Palavras-chave: greves operárias do ABC; novo sindicalismo; redemocratização.

\begin{abstract}
This article intends doing a critical approach, in a historical perspective, of studies about phenomenon broadly known as "novo sindicalismo" ("new unionism"), that has birth in the end of 70's and the beginning of 80's, settled by the workers' strikes happened at that time. It aims to identify the main comprehensive approaches that formed to the present day, especially in the fields of Social Sciences and Social History. The approach has as analytical axis some interfaces between the practical and discursive construction associated at "novo sindicalismo" and the Brazilian democratic issue.
\end{abstract}

Keywords: workers' strikes of $A B C$; new unionism; redemocratization.

\section{Introdução}

A transição do regime militar para a democracia foi planejada pelo governo Ernesto Geisel para ocorrer sob a forma de uma "distensão lenta, gradual e segura", uma "transição pelo alto". Naquele contexto, a irrupção dos conflitos operários do ABC paulista irradiou uma "onda de greves" pelo país afora em diversas categorias, como bancários, petroleiros, servidores públicos, canavieiros, entre outros. Ocorridas na passagem das décadas de 1970 para 1980, aquelas

* Mario Henrique Ladosky é doutor em Sociologia (USP), professor da Universidade Federal de Campina Grande (UFCG). Roberto Véras de Oliveira é doutor em Sociologia (USP), professor da Universidade Federal da Paraíba (UFPB), do Programa de Pós-Graduação em Sociologia (PPGS/UFPB) e do Programa de Pós-Graduação em Ciências Sociais (PPGCS/UFCG). 
mobilizações apontaram um claro questionamento aos limites políticos impostos e indicaram um anseio de participação popular para além do permitido. Tendo as novas práticas do Sindicato dos Metalúrgicos de São Bernardo do Campo e Diadema como uma importante referência e Lula como sua principal liderança, amplos segmentos dos trabalhadores criaram o que ficou conhecido como "novo sindicalismo". Da organização do polo mais combativo e atuante do movimento sindical, em combinação com uma miríade de outros movimentos sociais, nasceram algumas das principais entidades de extração popular que, nas décadas seguintes, tiveram papel destacado na reconstrução da democracia no país: o Partido dos Trabalhadores (PT), a Central Única dos Trabalhadores (CUT), o Movimento dos Trabalhadores Sem Terra (MST), a Central de Movimentos Populares (CMP) etc.

Este artigo tem por objetivo apresentar um balanço da produção intelectual produzida no país a respeito da experiência do "novo sindicalismo", principalmente nos campos da Sociologia e da História Social. Para tanto, está estruturado em três partes. A primeira refere-se ao debate a sobre o período que vai dos movimentos grevistas do final dos anos 1970 até o final dos anos 1980, quando a CUT já ocupava um destacado lugar no cenário político e sindical brasileiro. A segunda parte detém-se sobre as reflexões que sociólogos e historiadores fizeram sobre as consequências e posicionamentos sindicais frente às políticas neoliberais nos 1990. A terceira parte aborda a discussão que se estabeleceu sobre o papel do sindicalismo, com destaque para a CUT, nos governos Lula e Dilma. A última parte é reservada para as considerações finais.

\section{O "novo sindicalismo" e as novas abordagens sobre trabalho e trabalhadores}

A eclosão de um ciclo de greves operárias no ABC paulista, de 1978 a 1980, impactou fortemente a sociedade brasileira, ao trazer à cena púbica, de modo inusitado, um componente de forte participação popular e ao produzir uma reconfiguração da cena política. Na luta sindical e política de resistência e oposição ao regime militar, um polo se articulou em torno do que havia sido a perspectiva hegemônica na esquerda no período pré-64, a linha dos partidos comunistas tradicionais, o Partido Comunista Brasileiro (PCB) e o Partido Comunista do Brasil (PC do B), mais o Movimento Revolucionário 8 de outubro (MR-8). Naquele momento, este segmento reafirmou a estratégia de ocupação de espaços nas direções das entidades sindicais. Daí resultou uma composição com os dirigentes sindicais tradicionais, tidos como "pelegos" pelos setores mais atuantes. Essa foi a base de constituição do bloco da Unidade Sindical. De um ponto de vista mais amplo, visava contribuir com a constituição de uma frente ampla de oposição ao regime, que deveria sob o guarda-chuva do MDB incluir também setores do empresariado, intelectuais e artistas, entre outros.

Outro campo se formou a partir de três vertentes principais: os grupos de esquerda egressos da luta contra o regime; os militantes das Comunidades Eclesiais de Base (CEB) e das pastorais da Igreja Católica; e as lideranças sindicais que vinham promovendo iniciativas de organização de base (dirigentes sindicais "autênticos" e militantes de Oposições Sindicais), na luta por direitos trabalhistas e, dada a reação autoritária do regime, por bandeiras cada vez mais políticas. As greves de 1978 a 1980 foram decisivas para a constituição e projeção do "bloco 
combativo", base do "novo sindicalismo". Esse campo foi capaz de impulsionar uma ação contestatória mais radicalizada, articulada em torno da luta por reposição salarial (diante de uma crescente inflação, que depreciava o poder de compra dos trabalhadores) e por liberdade e autonomia sindical (pondo-se em oposição à estrutura sindical). Em termos partidários, foi um dos principais suportes para a fundação do Partido dos Trabalhadores (PT). A emergência deste, por sua vez, cristalizou um quadro de clara polarização no seio do sindicalismo brasileiro. ${ }^{1}$

Sobre aqueles acontecimentos e as perspectivas políticas que dali se desdobravam, PT ou "esquerda reformista", "novo sindicalismo" ou Unidade Sindical, os intelectuais, ao mesmo tempo em que firmavam suas interpretações, muitas vezes se posicionavam, de modo a também participarem das disputas políticas e ideológicas implicadas. Uma das mais influentes análises, naquele momento, foi formulada pelo cientista político Francisco Weffort, ${ }^{2}$ da USP, que viria a ser fundador e secretário geral do PT. A sua abordagem foi marcada pelo argumento de que teria havido uma ruptura entre, de um lado, o sindicalismo praticado de 1945 a 1964, sob a liderança do PCB e do PTB, por ele denominado de populista, e, de outro, uma nova perspectiva sindical esboçada com as greves operárias de Osasco e Contagem, em 1968, e consolidada com as greves operárias do $A B C$ paulista, entre 1978 e 1980.

O movimento sindical predominante no pré-64 teria tido uma atuação nos marcos do corporativismo, do populismo e do nacionalismo, primando por uma ação de cúpula e uma política de "conciliação de classe". Assim, no contexto de uma aliança com o governo João Goulart, não teria reunido condições de resistir ao golpe militar. O novo ambiente político teria inviabilizado a continuidade do sindicalismo populista. Mas, realça Weffort, ${ }^{3}$ em uma atitude de resistência operária, eclodiram as históricas greves de Osasco e de Contagem, sendo conduzidas por novas lideranças, com forte respaldo das bases, apoiadas em organizações nas fábricas e em franca oposição à política sindical do regime militar, tendo sido interrompidas com o retesamento da ditadura, especialmente com a decretação do Al-5 e novas intervenções do Ministério do Trabalho nos sindicatos.

Seguindo a mesma linha de raciocínio, o autor ${ }^{4}$ viu nas greves do $A B C$, uma década depois, a retomada, no contexto da abertura e redemocratização do país, daqueles elementos de uma nova concepção e prática sindical. Na sua leitura, o "novo sindicalismo" não representava apenas uma ruptura com a prática sindical controlada pela ditadura, voltada principalmente a uma agenda assistencialista. Também se diferenciava do sindicalismo populista do pré-64. Em contraste com este, suas principais marcas eram o enraizamento nos locais de trabalho, a oposição à estrutura sindical corporativista e a defesa da liberdade e autonomia sindical, tudo isso conformando uma perspectiva classista.

1 MERCADANTE, Aloísio; RAINHO, Luis Flavio. CUT e Conclat: a divisão política do movimento sindical. Aconteceu Especial - Trabalhadores urbanos no Brasil 82/84. São Paulo/Rio de Janeiro: CEDI, 16, 1986, p. 44-47; MOISÉS. “Qual é a estratégia do novo sindicalismo?” In: MOISÉS, J. A. et al (orgs.). Alternativas populares de democracia: Brasil anos 80, São Paulo: Vozes / CEDEC, 1982; e MOISÉS, José Álvaro. "Sociedade civil, cultura política e democracia: descaminhos da transição política”. In: COVRE, Ma de Lourdes M. (org.). A cidadania que não temos. São Paulo: Editora Brasiliense, 1986.

2 De Francisco Weffort ver: "Participação e conflito Industrial: Contagem e Osasco - 1968". Cadernos CEBRAP. São Paulo: Ed. CEBRAP, n 5, 1972; "Origens do sindicalismo populista no Brasil: a conjuntura do após-guerra". Estudos Cebrap, n 4, 1973; O populismo na política brasileira. Rio de Janeiro: Paz e Terra, 1974; e "Sindicalismo e democracia". Comunicação no Seminário sobre Direito, Cidadania e Participação. São Paulo: OAF/CEDEC/CEBRAP, mimeo., 1979.

3 WEFFORT. Participação e conflito Industrial.

4 WEFFORT. Comunicação no Seminário sobre Direito, Cidadania e Participação. 
À interpretação iniciada por Francisco Weffort, mesmo que com ênfases diversas, somaram-se os estudos de Humphrey, Moisés, Rainho, Rainho e Bargas, Garcia, 5 entre outros. Contrário à linha weffortiana, afirmaram-se posições como as de Rodrigues, Rodrigues e Munhoz, Vianna, Almeida ${ }^{6}$ etc. Outros procuraram relativizar a análise de Weffort, como Troyano, Maranhão e Delgado.7

Perspectivas, como a de Vianna ${ }^{8}$ se pautaram na defesa das conquistas da militância do PCB no período pré-64, embora reconhecendo as limitações políticas e sindicais da época, assim como se voltaram à defesa dos caminhos indicados por tal corrente no processo de reorganização sindical desencadeado em fins dos anos 1970.

Um dos mais importantes momentos do debate acadêmico referido àquele contexto envolveu Rodrigues, ${ }^{9}$ Almeida ${ }^{10}$ e Humphrey, ${ }^{11}$ quando estes se dedicaram a discutir se a reconfiguração da classe operária do $A B C$, especialmente do setor automobilístico, estaria dando origem a um modelo de ação e de organização diferenciado dos demais segmentos dos trabalhadores. Para Rodrigues, os salários relativamente mais altos e a política de promoções das empresas do setor, a origem rural de grandes contingentes de operários oriundos e a política salarial do governo (que previa reajustes salariais automáticos, de acordo com a inflação) concorriam para um estado de "satisfação" generalizado entre os trabalhadores, o que os impedia de adquirir uma "consciência anticapitalista".

Quanto à Almeida, com o desenvolvimento da "indústria moderna” no país, a classe trabalhadora teria passado por um amplo processo de diversificação interna, ao mesmo tempo em que a legislação trabalhista se mantinha a mesma, preconizando soluções uniformes. Assim, a tendência seria de crescente conflito entre os "novos problemas" e as "velhas estruturas". A autora se referia a uma nova prática sindical, que começava a surgir nos segmentos mais "modernos" do operariado industrial, particularmente no $A B C$ paulista. Sua característica principal era a mobilização em torno dos conflitos típicos dos processos de trabalho das grandes empresas, geralmente multinacionais. A diferenciação interna sofrida pelo operariado, com o

5 HUMPHREY, John. "Operários da indústria automobilística no Brasil: novas tendências no movimento trabalhista”. Estudos Cebrap. Rio de Janeiro: Vozes, n²23, 1979; HUMPHREY, John. "As raízes e os desafios do 'Novo' sindicalismo na indústria automobilística”. Estudos Cebrap. Rio de Janeiro: Vozes, n 26, 1980; HUMPHREY, John. Fazendo o milagre. Petrópolis: Vozes/CEBRAP, 1982; MOISÉS, José Álvaro. Greve de massa e crise política. São Paulo: Pólis, 1978; MOISÉS. "Qual é a estratégia do novo sindicalismo?”; MOISÉS, José Álvaro. Lições de liberdade e de opressão, Rio de Janeiro, Paz e Terra, 1982b; MOISÉS. "Sociedade civil, cultura política e democracia”; RAINHO, Luís Flávio. Os peões do grande ABC. Rio de Janeiro: Ed. Vozes, 1980; RAINHO, Luís Flávio; BARGAS, Osvaldo. As lutas operárias e sindicais dos metalúrgicos em São Bernardo (1977-1979). São Bernardo do Campo: FG, 1983; e GARCIA, Marco Aurélio. "São Bernardo: A (auto) construção de um movimento operário". Desvios. São Paulo, ano 1, n 1, 1982.

6 RODRIGUES, Leôncio Martins. Industrialização e atitudes operárias. São Paulo: Brasiliense, 1970; RODRIGUES, Leôncio Martins e MUNHOZ, Fábio A. "Bibliografia sobre trabalhadores e sindicatos no Brasil”. Estudos CEBRAP. São Paulo: CEBRAP, n 7, 1974; VIANNA, Luis Werneck. "Estudos sobre sindicalismo e movimento operário: resenha de algumas tendências". In: O que se deve ler em Ciências Sociais no Brasil. São Paulo: ANPOCS / Cortez Editora, $\mathrm{n}^{\circ}$ 1, 1977; Idem. Liberalismo e sindicalismo no Brasil. Rio de Janeiro: Paz e Terra, 1978; Idem. “Atualizando uma bibliografia: 'Novo Sindicalismo', Cidadania e Fábrica”'. In: O que se deve ler em Ciências Sociais no Brasil. São Paulo: ANPOCS / Cortez Editora, $n^{\circ}$ 3, 1983; e ALMEIDA, Maria Hermínia Tavares de. "Sindicato no Brasil: novos problemas, velhas estruturas". Debate e Crítica. São Paulo: Hucitec, p. 32-60, 1975.

7 TROYANO, Annez. Estado e sindicalismo. São Paulo: Símbolo, 1978; MARANHÃO, Ricardo. Sindicatos e redemocratização. São Paulo: Brasiliense, 1979 e DELGADO, Lucília de Almeida Neves. O comando geral dos trabalhadores no Brasil - 1961/1964. Petrópolis: Vozes, 1986.

8 Ver os trabalhos de VIANNA de 1977, 1978, 1983.

9 RODRIGUES. Industrialização e atitudes operárias.

10 ALMEIDA. Sindicato no Brasil.

11 HUMPHREY. As raízes e os desafios do ‘Novo’ sindicalismo na indústria automobilística. 
desenvolvimento da indústria “moderna" no país, estaria implicando na diversificação dos conflitos fabris, assim como suscitava uma nova perspectiva de ação sindical, se comparada com o padrão anterior a 1964, tipicamente "populista". Esse "novo sindicalismo" caracterizar-se-ia pela rejeição da tutela do Estado e pelo empenho em realizar negociações coletivas ao nível das empresas. Mas, graças à segmentação do mercado de trabalho, os setores mais "modernos" do operariado fabril tenderiam a uma prática sindical "divisionista" e próxima do "sindicalismo de negócios".

Referindo-se a Rodrigues e Almeida, Humphrey contesta as teses da "ideologia do atraso" (expressão de Weffort), da "aristocracia operária" e do "sindicalismo de negócios", como aplicáveis aos operários dos setores "dinâmicos" da economia brasileira. Admite que estes traziam características diferenciadas em relação aos trabalhadores das indústrias "tradicionais". Contudo, mesmo o "milagre econômico" aprofundando as diferenciações na classe operária, um maior controle estatal sobre os sindicatos e a adoção de uma política salarial centralizada e orientada para o "arrocho" tinham contribuído para que surgissem novas formas de ação coletiva. Os primeiros sintomas disso teriam sido as greves de Osasco e Contagem, ocorridas em 1968, as quais tinham em comum o fato de se situarem em setores "dinâmicos" da indústria e terem sido resultado da mobilização das bases operárias, mais do que das cúpulas sindicais.

No estudo que empreendeu particularmente sobre o setor automobilístico, Humphrey notou que os salários ali praticados, apesar de serem muito mais altos do que os verificados na média da indústria, teriam sido alvo igualmente dos rigores da política salarial do governo. Além disso, observou que os salários mais elevados tinham como contrapartida maiores exigências em termos de disciplina e de intensidade do trabalho. Constatou, ainda, que os operários do setor demonstravam insatisfação em relação à evolução de seus salários, à intensificação do trabalho, à rotatividade da mão de obra, entre outros problemas. De tal maneira, entre 1974-75, os operários dos setores dinâmicos teriam assumido novamente um papel de liderança.

A apreensão dos movimentos sociais emergentes como novos sujeitos políticos autônomos, embora sob ênfases diversas, foi uma referência em vários estudos produzidos naquela ocasião e depois. São exemplos: Maroni, Moisés, Singer e Brant, Abramo, Sader, Lobo, ${ }^{12}$ toda produção da Revista Desvios, ${ }^{13}$ entre outros. Por essa via ficou evidenciado o impacto das práticas coletivas das classes populares sobre as próprias maneiras de apreendê-las, através de tais estudos. Ou seja, a novidade também estava na maneira de nomear o "novo". Quanto a isso, Sader e Paoli identificam uma ruptura, nesse período, no modelo interpretativo das ciências sociais sobre a sociedade brasileira, particularmente no que se refere à "imagem dos trabalhadores".

12 MARONI, Amnéris. A estratégia da recusa (Análise das greves de maio de 78). São Paulo: Ed. Brasiliense, 1982; MOISÉS. “Qual é a estratégia do novo sindicalismo?”; ABRAMO, Laís Wendel. O resgate da dignidade: greve metalúrgica e subjetividade operária. Campinas: Editora da Unicamp; São Paulo: Imprensa Oficial, 1999; LOBO, Elisabeth Souza. A classe operária tem dois sexos. São Paulo: Editora Brasiliense e Secretaria Municipal de Cultura de São Paulo, 1991 e SADER, Eder. Quando novos personagens entram em cena: experiências e lutas dos trabalhadores da Grande São Paulo, 1970-1980. Rio de Janeiro: Ed. Paz e Terra, 1988.

13 A Revista Desvios, cujo primeiro número saiu em setembro de 1980, produzindo edições anuais de 1982 até 1986, foi criada e mantida por um grupo de intelectuais de esquerda, tanto militantes políticos como acadêmicos. Dedicava-se à abordagem das diversas formas de existência dos "novos movimentos sociais", tendo como elemento orientador comum a ideia de "autonomia" (daí a denominação informal de "grupo dos autonomistas"). Nela foram veiculados artigos de Marilena Chaú́, Marco Aurélio Garcia, Eder Sader, Maria Célia Paoli, Vera Telles, Amnéris Maroni, Silvio Caccia Bava, entre outros. 
Diante da contundência das lutas coletivas do período, produziu-se um flagrante descompasso entre elas e as representações instituídas nas ciências sociais sobre as classes populares. Na crise de interpretação assim estabelecida, firmou-se um novo paradigma interpretativo: o das representações instituintes:

Os pesquisadores das ciências sociais dos anos 80 se viram diante de um momento político marcado por movimentos vários de luta contra opressões diversas, a maioria de base popular, cuja promessa tirava de cena os atributos de 'alienação' e heteronomia tradicionalmente atribuídos aos trabalhadores. ${ }^{14}$

Assim, o foco das abordagens acadêmicas e políticas, ao invés de continuar centrado no Estado como espaço e agente privilegiado das mudanças sociais, deslocou-se para a tensão entre a "sociedade civil" e o Estado. As referências teóricas adotadas nas novas interpretações foram diversas, mas em comum trouxeram um profundo questionamento de quaisquer tipos de determinismos, que nas abordagens sobre trabalhadores e classes populares negligenciavam nestes alguma capacidade de iniciativa autônoma. Foram muito importantes nesse momento as influências de E.P. Thompson, Cornelius Castoriadis, Claude Lefort ${ }^{15} \mathrm{e}$ principalmente Antônio Gramsci. Este, em particular por meio de conceitos como hegemonia, bloco histórico e intelectual orgânico, inspirou mais amplamente a militância à crítica das visões "economicistas" (propugnadas pelo "marxismo vulgar") e "voluntaristas" (um dos principais elementos da autocrítica da esquerda naquele momento). Como notou Sader:

Grupos de militantes desgarrados, dispersados com a desarticulação das organizações de esquerda, iam buscar novas formas de 'ligação com o povo', alternativas ao vanguardismo derrotado. Na verdade seu autor de cabeceira não era o educador cristão exilado do Brasil [Paulo Freire], mas Antonio Gramsci, cujas teses sobre a cultura popular e sobre o partido como intelectual coletivo pareciam abrir outras pistas para uma prática política. ${ }^{16}$

No período aqui considerado, estabeleceu-se uma correspondência de sentidos entre os "novos movimentos sociais" e as "novas abordagens". Da parte daqueles movimentos, da sua prática crítica e de seu exercício de autonomia, foi suscitada uma reinterpretação da realidade histórico-social e de si próprios, que demandou dos intelectuais esforços nesse sentido. De outra parte, constituiu-se

14 SADER, Eder e PAOLI, Maria Célia. Sobre ‘Classes Populares' no pensamento sociológico brasileiro (notas de leitura sobre acontecimentos recentes). In: CARDOSO, Ruth (org.). A aventura antropológica, Rio de Janeiro: Ed. Paz e Terra, 1986. p. 60.

15 THOMPSON, E. P. A miséria da teoria ou um planetário de erros. Rio de Janeiro: Zahar Editora, 1981. Idem. "La sociedad inglesa del siglo XVIII: lucha de clases sin clases?" In: Tradición, revuelta y consciencia de clase. Barcelona: Editorial Crítica, 1984; Idem. A formação da classe operária inglesa. Rio de Janeiro: Paz e Terra. 1987; Idem. Costumes em comum: estudos sobre a cultura popular tradicional. São Paulo: Companhia das Letras, 1998; CASTORIADIS, Cornelius. A instituição imaginária da sociedade. Rio de Janeiro: Ed. Paz e Terra, 1982; Idem. "Introdução: A questão da História do Movimento Operário (1973)". In: A experiência do movimento operário. São Paulo: Editora Brasiliense, 1985; Idem. Poder, política, autonomia. In: O mundo fragmentado: as encruzilhadas do labirinto. Rio de Janeiro: Paz e Terra, 1992; LEFORT, Claude. A invenção democrática: os limites do totalitarismo. São Paulo: Editora Brasiliense, 1983.

16 SADER. Quando novos personagens entram em cena, p. 167. 
uma "geração" de intelectuais (entre acadêmicos e militantes, jovens e veteranos, com diversas formações) que, não obstante suas diferenças, reconheceram aqueles movimentos como "sujeitos políticos autônomos" (e, portanto, dotados de sentidos, valores, racionalidade próprios), dignos de serem tomados como um campo prioritário de reflexão.

\section{A institucionalização do "novo sindicalismo" e os novos esforços interpretativos}

A disputa entre os "sindicalistas combativos" e a Unidade Sindical ganhou contornos mais nítidos na $1^{\mathrm{a}}$ Conferência Nacional da Classe Trabalhadora ( $1^{\mathrm{a}}$ CONCLAT), realizada em 1981. Este foi o único encontro intersindical do período, tendo reunido as principais correntes do conjunto do sindicalismo brasileiro. Ao final da Conferência, constituiu-se uma Comissão Nacional Pró-CUT, expressiva da heterogeneidade política dos congressistas, com a incumbência de fundar a Central Única dos Trabalhadores, em 1982. Entretanto, às vésperas da realização do Congresso convocado com tal fim, a maioria da referida Comissão, formada por dirigentes ligados à Unidade Sindical, alegou necessidade de adiá-lo para o ano seguinte. Na preparação do Congresso que deveria fundar a CUT em 1983, as divergências foram evidenciadas. ${ }^{17}$ Então, sentindo que haveria novo adiamento, os dirigentes ligados ao "novo sindicalismo" romperam com a Comissão Pró-CUT e convocaram, sozinhos, o Congresso que viria a fundar a CUT em 28 de agosto de 1983. Diante do fato, por sua vez, em novembro daquele mesmo ano, os setores articulados em torno da Unidade Sindical realizaram o Congresso que criou a Coordenação Nacional da Classe Trabalhadora, aproveitando a sigla CONCLAT. Em 1986, a CONCLAT se definiu como central sindical, passando a assumir a denominação de Central Geral dos Trabalhadores (CGT). ${ }^{18}$

O primeiro período de existência da CUT se estendeu de sua fundação, em 1983, até a virada da década de 1980 para 1990, tendo no $3^{\circ}$ Congresso Nacional da CUT ( $3^{\circ}$ CONCUT), em 1988, o momento que marcou uma inflexão em sua trajetória. Visando consolidar-se como principal central sindical do país, a CUT, cuja base era constituída majoritariamente por Oposições Sindicais e alguns sindicatos oficiais, optou por disputar as diretorias dos sindicatos oficiais, por meio de eleições sindicais, tendo como propósito em seguida transformá-los em "instrumentos de luta dos trabalhadores", de modo a romper na prática com a estrutura sindical corporativa. A adoção de tal estratégia foi resultado de um debate interno ao Bloco Combativo, entre a opção de transformar as entidades sindicais "por dentro" ou fazer das Oposições Sindicais um "sindicato paralelo" à estrutura corporativa, sendo esta última posição defendida principalmente pelo Movimento de Oposição Metalúrgica de São Paulo (MOMSP), principal grupo de oposição sindical cutista. ${ }^{19}$

17 A gota d'água no artigo $8^{\circ}$ do regimento interno, sobre critério de participação como delegado. Para o "bloco combativo" poderia haver representação de trabalhadores de base e de oposições sindicais de base. Isso era inaceitável para a Unidade Sindical, uma vez que, na opinião deles, tais militantes careciam de legitimidade e de representatividade para serem delegados no CONCLAT. Para a militância do "novo sindicalismo" esse era um ponto de honra, uma vez que compreendiam que a representatividade de um delegado não estava necessariamente relacionada a um cargo de direção no sindicato, mas em sua atuação na luta dos trabalhadores, que o legitimaria a ser eleito delegado em assembleia da categoria.

18 No final dos anos 1980, as correntes sindicais ligadas ao PCB e ao PCdoB (respectivamente, Unidade Sindical e Corrente Sindical Classista) deixaram a CGT e se filiaram à CUT.

19 As relações dos sindicalistas "autênticos" com as "oposições sindicais" sempre foram marcadas por 
A constituição e o acompanhamento das Oposições Sindicais foram, portanto, partes decisivas dessa estratégia.

Ao longo dos anos 1980, a combinação de elevados índices de inflação com arrocho salarial imposto pela política econômica dos sucessivos governos e um ambiente político de redemocratização que permitia maior liberdade de expressão e manifestação pesou a favor da disposição de diversos segmentos das classes trabalhadoras em se lançarem em lutas coletivas, na defesa de reivindicações salariais, sociais e políticas. Dados de Noronha ${ }^{20}$ indicaram crescimento de aproximadamente $1.800 \%$ no número de greves, de 1978 a 1988. De acordo com Noronha, "no final dos anos 1980, o volume de greves no Brasil estava entre os mais altos do mundo, sendo que há pouco mais de uma década elas praticamente inexistiam". ${ }^{21}$ Essa situação favoreceu o crescimento e a influência da CUT.

Quanto à presença do Sindicalismo CUT ${ }^{22}$ no cenário político do país, alguns momentos ganharam maior destaque: as greves de categorias com expressão nacional (metalúrgicos, bancários, petroleiros, professores, funcionários públicos etc.); as greves gerais em oposição aos sucessivos planos macroeconômicos de combate à inflação (a começar pelo Plano Cruzado, em 1986); ${ }^{23}$ a participação no processo constituinte, do qual resultou a promulgação de uma nova Constituição, em 1988, entre outros.

A necessidade de se firmar no movimento sindical e na sociedade pautou um padrão de ação sindical conflitivo. ${ }^{24} \mathrm{O}$ efeito dessa postura no crescimento da

aproximações, mas também por diferenças e tensões. Pela proximidade geográfica e de setor econômico, a relação dos sindicalistas do $A B C$ foi mais intensa com a Oposição Sindical Metalúrgica de São Paulo (OSM). Nesse caso, uma questão sobressaiu: o debate sobre as comissões de fábricas e suas relações com os sindicatos (cujas inspirações principais eram as experiências da Cobrasma em Osasco, na greve de 1968, e das Comisiones Obreras da Espanha). O que veio depois a ser denominado de MOSMSP buscava articular um trabalho de organização dos trabalhadores nas fábricas com uma intervenção crítica junto ao Sindicato dos Metalúrgicos de São Paulo, apontando para uma futura ruptura com a estrutura sindical oficial. Entretanto, com os reveses sofridos após o ciclo de greves de 1978 a 1979 (produto das perseguições empreendidas pelos patrões e da capacidade de rearticulação da diretoria desse sindicato, que passou a contar com o apoio de militantes do P( e do MR-8), o MOSMSP perdeu espaço em um momento decisivo para a redefinição dos rumos do sindicalismo metalúrgico em São Paulo e do sindicalismo no país. Ao mesmo tempo a experiência do $A B C$ estava em ascensão e fortalecia sua influência sobre o sindicalismo cutista, incluindo os grupos de oposições sindicais espalhados pelo país.

20 NORONHA, Eduardo. "A explosão das greves na década de 80". In: BOITO Jr., Armando (org.). 0 sindicalismo brasileiro nos anos 80. Rio de Janeiro: Paz e Terra, 1991.

21 NORONHA, Eduardo. "Greves e estratégias sindicais no Brasil”. In: OLIVEIRA, C. A. B. de et al (orgs.). O mundo do trabalho: crise e mudança no final do século. São Paulo: MTb/PNUD; CESIT/UNICAMP: Scritta, p. 323-326, 1994 .

22 O termo sindicalismo CUT é de Jácome Rodrigues (1993). Sugere um campo de experiências sindicais, envolvendo sindicatos, federações, confederações, organismos de representação de base, instâncias orgânicas à Central etc., perpassado por diversas correntes e agrupamentos políticos, mas de algum modo reportado à construção simbólica CUT e/ou à instituição CUT. Daí porque procuramos evitar denominá-lo simplesmente de CUT (para não tê-lo somente no seu sentido formal, institucional). Às vezes o denominamos também de sindicalismo cutista, mas sem dar-lhe preferência, visto que tal pode sugerir a idéia de uma experiência politicamente monolítica.

23 Ao longo de sua trajetória, a CUT convocou os trabalhadores a participarem de cinco greves gerais: em 21 de julho de 1983, 12 de dezembro de 1986, 20 de agosto de 1987, 14 e 15 de março de 1989 e a última em 22 e 23 de maio de 1991. Há que se ressaltar que as bandeiras levantadas a cada greve geral não eram de cunho estritamente trabalhista/salarial, mas via de regra, apresentava bandeiras como "reforma agrária radical sob controle dos trabalhadores" e o "não pagamento da dívida externa" como reivindicações da classe. A partir dos anos 1990, com o novo contexto sócio-político e econômico do país, o refluxo do movimento grevista e a mudança de orientação no padrão de ação sindical da CUT, a central sindical abandonou a estratégia de convocação de greves gerais. As maiores mobilizações "de massa” convocadas pela CUT em diversas ocasiões a partir de então passou a ser Dia Nacional de Luta, e as Marchas a Brasília.

24 JÁCOME RODRIGUES, Iram. "Sindicalismo, emprego e relações de trabalho na indústria automobilística". In: ANTUNES, Ricardo (org.). Neoliberalismo, trabalho e sindicatos: reestruturação no Brasil e na Inglaterra. São Paulo: Boitempo Editorial, 1997. 
CUT nos anos 1980 foi contundente, tendo passado de 912 sindicatos filiados, no Congresso de fundação, em 1983, para 1.143 sindicatos, no $3^{\circ}$ CONCUT, em 1988: um crescimento de $25 \%$ em cinco anos de existência.

No $1^{\circ}$ CONCUT, realizado em 1984, foram declarados os princípios que orientariam a política da CUT: classista, democrática, organizada pela base, de massa, em defesa da liberdade e autonomia sindical. Na ocasião, firmou-se como horizonte da Central a defesa dos "interesses históricos e imediatos da classe trabalhadora", numa alusão ao socialismo. Ali também foram lançadas as bases do seu projeto organizativo, a partir de uma composição entre estruturas verticais (sindicatos e, com menor ênfase, federações e confederações) e horizontais (CUT Nacional, CUTs estaduais e CUTs regionais).

O $2^{\circ}$ CONCUT, em 1986, começou a expor mais claramente as diferenças que iriam marcar sua trajetória daí por diante, opondo uma visão de tipo mais confrontacionista e assumidamente de referência mais socialista e outra de natureza centralmente voltada a um papel de negociação e de contratação coletiva e, portanto, à afirmação da CUT como central sindical. Embora os defensores da primeira tenha conseguido aprovar nas resoluções uma menção explícita ao socialismo, a segunda já se esboçava como corrente majoritária. Giannotti e Neto, analista do sindicalismo e militante identificado com a primeira corrente, assim avaliou o Congresso:

A partir desse Congresso, a tendência majoritária começa a imprimir à Central um estilo autoritário, hegemônico, que irá provocar vários tensionamentos e polêmicas na CUT. Junto com isso, passou a ser imprimido na Central um ritmo acelerado, na adoção de uma estrutura orgânica, de forte influência europeia. O resultado disso aparecerá no Congresso seguinte. ${ }^{25}$

Para Iram Jácome Rodrigues,

Se o $2^{\circ}$ CONCUT representou um forte impulso para a esquerda do sindicalismo-CUT, significou também um acirramento da luta política e ideológica entre as principais correntes políticas. Foi o último momento onde a esquerda socialista conseguiu imprimir sua marca mais fortemente. A partir daí, independentemente das questões políticas e organizativas, aqueles setores, que poderíamos chamar de esquerda sindical ou contratualista (a Articulação Sindical e seus aliados), passaram a definir mais concretamente o jogo político-sindical da CUT. Foi assim no $3^{\circ}$ CONCUT e, - apesar das dificuldades - também no $4^{\circ}$ CONCUT. ${ }^{26}$

O $3^{\circ}$ CONCUT, realizado em 1988, representou um marco na transição de uma “CUT - movimento" para uma "CUT - Instituição". Conforme Giannotti e Neto:

O $3^{\circ}$ Congresso - Belo Horizonte, 1988 -, foi quase todo absorvido pela discussão sobre a reestruturação da CUT, enquanto máquina sindical (...) O objetivo da maioria da Direção era claro: aprovar uma mudança no estatuto que permitisse implementar uma nova visão de Central. Uma

25 GIANNOTTI, Vito; NETO, Sebastião Lopes. CUT por dentro e por fora. Petrópolis: Vozes, p. 43, 1991 a.

26 JÁCOME RODRIGUES. "Sindicalismo, emprego e relações de trabalho na indústria automobilística”, p. 109. 
Central de representação, de negociação, mais do que uma Central de mobilização e organização para a luta de amplas massas. ${ }^{27}$

A CUT se tornara uma entidade que congregava um número cada vez maior de sindicatos oficiais da estrutura corporativa, conquistados ao longo da década de 1980, o que aumentava o peso dos temas da representação e da negociação coletiva e, consequentemente, ampliava a importância dos sindicatos em detrimento das oposições sindicas.

Outros fatores que vieram a ocorrer posteriormente ao $3^{\circ} \mathrm{CONCUT}$ influíram sobre o contexto dos anos 1990 e os rumos do Sindicalismo CUT. A vitória de Collor na corrida presidencial de 1989 Ihe conferiu uma legitimidade que faltava ao governo da Nova República, eleito indiretamente pelo Congresso Nacional. Como consequência, o brado de "Fora Collor", proposto por setores minoritários da Direção da CUT, soaria, na interpretação política dos setores majoritários, como uma ação golpista. ${ }^{28}$ Some-se a isso a queda do Muro de Berlim, símbolo do colapso da experiência do "socialismo real", cujas principais expressões foram a União das Repúblicas Socialistas Soviéticas (URSS) e demais países do leste europeu. O reflexo destes reveses político-ideológicos, na ocasião, foi interpretado pelo setor majoritário da Direção da CUT como sinalização da necessidade de maior ponderação e menos radicalismo nas posições políticas. Foi assim que, sob a influência da corrente majoritária, esse Congresso priorizou o fortalecimento institucional da Central.

Nos termos de Iram Jácome Rodrigues:

Em outras palavras, o que estava em jogo neste congresso eram duas alternativas para o sindicalismo-CUT: a primeira, da CUT-movimento; a segunda, da CUT-organização. Esta venceu... Iniciava-se realmente a implantação da CUT como estrutura verticalizada, administrativa, enfim, como uma organização complexa e, nesse sentido, burocrática (...) Simbolicamente, esse encontro significou o fim da fase heroica de construção da CUT e tudo o que ela representava para uma parte da militância cutista (...) E, em consonância, com o processo de democratização do país, setores ponderáveis do sindicalismo-CUT começavam a vislumbrar a possibilidade das classes trabalhadoras influírem mais decididamente na esfera política e, para isso, era necessário deixarem de dizer apenas não e também indicarem soluções para os problemas sociais, políticos e econômicos do país. ${ }^{29}$

A projeção conquistada pela CUT no sindicalismo brasileiro ao longo dos anos 1980 foi acompanhada pelo interesse de estudiosos do trabalho em pesquisar sobre sua trajetória e vicissitudes. Nesse sentido, o estudo de Leôncio Martins Rodrigues sobre a CUT foi pioneiro. O mesmo se baseou na aplicação de um questionário junto aos delegados ao $3^{\circ}$ CONCUT com o objetivo de traçar-lhes o perfil. Os

27 GIANNOTTI, Vito; NETO, Sebastião Lopes. Para onde vai a CUT? São Paulo: Scritta, p. 42, 1993.

28 No início do governo Collor, a direção da CUT adotou a palavra-de-ordem "Não a Collor”, ou seja, não à sua política recessiva, ao desemprego, ao arrocho salarial. Na ocasião, a maioria dos dirigentes da Central avaliou que o slogan "Fora Collor", proposto pelas correntes minoritárias, significaria ir contra as regras democráticas estabelecidas no país. Nessa visão, caberia à CUT fazer oposição ao governo, mas não propor sua saída. Em 1992, na $5^{\text {a }}$ Plenária Nacional, a CUT mudaria sua posição diante das denúncias de corrupção, que levaram a manifestações de massa e a seu impeachment.

29 RODRIGUES. Sindicalismo, emprego e relações de trabalho na indústria automobilística, p. 117. 
resultados foram publicados em Rodrigues e em CUT. ${ }^{30}$ Em Rodrigues consta também uma abordagem histórica sobre a Central. Na sua avaliação, apesar desta ter realizado nos anos 1980 "um notável avanço organizatório", teria ocorrido com isso um aumento do seu controle sobre a estrutura sindical oficial, resultando daí um contraste "entre a retórica radical de exaltação de um sindicalismo de classe e de base e o esforço para a conquista de diretorias nos sindicatos oficiais". ${ }^{11}$ Para o autor, se "o ethos socialista que dá o tom à cultura política da CUT (...) indicativo de que a motivação básica de grande parte dos dirigentes e quadros médios é mais política do que sindical", a sua ação cotidiana, em contraste, caracterizar-seia "pelo ramerrão administrativo, pelos conchavos que antecedem as eleições no próprio sindicato, pelas enfadonhas reuniões de diretoria...".32

Os momentos de maior "radicalização" seriam mesmo aqueles dos congressos. Rodrigues tomou como parâmetro de sua observação a "função" que estaria reservada para o sindicalismo numa sociedade como a brasileira, com fortes características de uma sociedade "moderna", mas com particularidades tais que colocaria para o sindicalismo local a "vantagem" de se apoiar no tradicional "modelo sindical corporativista". Entretanto, o "ethos socialista" presente na CUT passara a ser "disfuncional". Por isso, propõe, ao contrário, que esta busque reforçar uma perspectiva mais "negocial" e "pragmática", assumindo como "vantajosa" a sua relação com a estrutura sindical corporativista.

Já os diagnósticos de Antunes ${ }^{33}$ contrastam com os de Rodrigues. Aquele identificou na "rebeldia do trabalho" à "superexploração" o elemento capaz de possibilitar a passagem "histórica" de uma forma "contingencial" para uma "forma essencial de ser da classe trabalhadora", mais "consciente", quando teria assumido uma perspectiva "socialista". Mas vislumbrou dificuldades crescentes de articulação das "lutas imediatas" com as "lutas históricas", com isso alimentando uma tendência "social-democrata" no seu interior, que a distanciava de suas origens no "novo sindicalismo". Como isso concordam Giannotti e Neto, que também alertam para o risco iminente de uma "hegemonização social-democrata" e de "burocratização" crescente da CUT.

Jácome Rodrigues ${ }^{34}$ abre outra vertente interpretativa, sugerindo como "fim último" das greves dos anos 1980 a luta pela "cidadania política dos trabalhadores", com a CUT tendo se constituído no principal canal de expressão das "demandas das classes trabalhadoras por cidadania política". Ao mesmo tempo observa que, se inicialmente se utilizava do "confronto" para chegar à "negociação", com a institucionalização trazida pelo processo de "transição democrática”, tal estratégia estaria se esgotando. Assim, a crise pela qual passava o Sindicalismo CUT resultava do seu crescimento e institucionalização.

30 RODRIGUES, Leôncio Martins. CUT: Os militantes e a ideologia. Rio de Janeiro: Ed. Paz e Terra, 1999 a. Idem. CUT. Retrato da CUT. São Paulo: CUT, 1991a.

31 RODRIGUES. CUT: Os militantes e a ideologia, p. 93-94.

32 Idem, p. 87-88.

33 ANTUNES, Ricardo. A rebeldia do trabalho. Campinas: Editora da UNICAMP; São Paulo: Ensaio, 1988; Idem. O novo sindicalismo. São Paulo: Ed. Brasil Urgente, 1991ª Idem. "Além dos muros da Universidade". Forma e Conteúdo. São Paulo: SNF-CUT, nº 04, set. 1991b.

34 JÁCOME RODRIGUES, Iram. "As comissões de empresa e o movimento sindical”. In: BOITO Jr., Armando (org.). O sindicalismo brasileiro nos anos 80; Idem. Trabalhadores, sindicalismo e democracia: a trajetória da CUT. São Paulo, Tese (Doutorado em Sociologia), USP, 1993, Idem. "Sindicalismo, emprego e relações de trabalho na indústria automobilística”. In: ANTUNES, Ricardo (org.). Neoliberalismo, trabalho e sindicatos; Idem. "A trajetória do novo sindicalismo". In: JÁCOME RODRIGUES, Iram (org.). O novo sindicalismo vinte anos depois. Rio de Janeiro: Editora Vozes; São Paulo: Educ/Unitrabalho, 1999; Idem. "Um laboratório das relações de trabalho: o ABC paulista nos anos 90". Comunicação ao XXV Encontro Anual da Anpocs, Caxambu, out., 2001. 
Boito Jr. ${ }^{35}$ analisou os dilemas do sindicalismo brasileiro nos anos 1980 a partir da sua apreensão enquanto uma "estrutura", na qual encontrar-se-ia determinado o seu próprio "funcionamento" e "reprodução". Dada a estratégia da CUT, de atuar por dentro do "sindicato de Estado", não obstante os "avanços" realizados, não se constituíra em uma força social capaz de, "conscientemente", levar a uma ruptura com tal "estrutura".

Almeida, ${ }^{36}$ com um foco sobre as estratégias sindicais, se limita a buscar desvendar as razões da reafirmação de tal estratégia ao longo da década e compreender os motivos da perda do impulso para mudanças mais radicais na estrutura sindical corporativista. Constata, quanto ao primeiro aspecto que, ao mesmo tempo em que se fortaleceu como ator político no cenário do país, o sindicalismo conquistou uma vitória de Pirro (na corrida pela indexação salarial). E, quanto ao segundo, que as mudanças realizadas no modelo sindical estavam longe das proposições do novo sindicalismo. Admite que a "estratégia confrontacionista" havia se esgotado, mas não propôs alternativas, ao contrário dos autores anteriores.

Nesta parte nos detemos nos estudos realizados entre final da década de 1980 e metade da década de 1990 e que tiveram como foco a realização de balanços do "novo sindicalismo" e do Sindicalismo CUT até aquele período. ${ }^{37}$ Em um momento no qual sobressaíam, nessa experiência sindical, elementos de institucionalização - ou de burocratização, com alguns preferiram -, as mais destacadas abordagens se orientaram por referenciais teóricos que, embora diversos, distanciaramse daquele inspirado na noção de autonomia e fartamente utilizado no período anterior.

Estudos como Jácome Rodrigues, Mangabeira, Veras de Oliveira, Ladosky, Santana, ${ }^{38}$ entre outros, embora com ênfases diferentes, também buscaram apreender o referido processo de institucionalização, ao mesmo tempo sem perder de vista suas possibilidades de reinvenção como sujeito político (elementos, esses, que marcaram as abordagens sobre a emergência do "novo sindicalismo"). Daí resultaram diagnósticos que realçaram elementos de ruptura, mas também de continuidade na relação entre a trajetória do "novo sindicalismo"/sindicalismo CUT e a estrutura sindical corporativista, com seus desdobramentos futuros sempre colocados em aberto.

Nesse mesmo período, uma perspectiva claramente thompsoniana inspirou

35 BOITO Jr, Armando. O sindicalismo de Estado no Brasil; Idem. "Reforma e persistência da estrutura sindical". In: BOITO Jr, Armando (org.). O sindicalismo brasileiro nos anos 80; Idem. "De volta para o novo corporativismo - A trajetória política do sindicalismo brasileiro”. São Paulo em Perspectiva. São Paulo: Fundação Seade, $n^{\circ}$ 3, 1994.

36 ALMEIDA, Maria Hermínia Tavares de. Crise econômica e interesses organizados: o sindicalismo no Brasil dos anos 80. São Paulo: Edusp, 1996.

37 Cujos principais argumentos estão sintetizados nas coletâneas organizadas por Boito Jr. (O sindicalismo brasileiro nos anos 80) e Jácome Rodrigues ("A trajetória do novo sindicalismo").

38 JÁCOME RODRIGUES, Iram. Trabalhadores, sindicalismo e democracia: a trajetória da CUT. São Paulo, Tese (Doutorado em Sociologia), USP, 1993; Idem. "Perspectivas do sindicalismo no Brasil: o caso da CUT". In: DINIZ, E; LOPES, J. S. L.; PRANDI, R. (orgs.). O Brasil no rastro da crise. São Paulo: ANPOCS/Hucitec/IPEA, 1994; Idem. "O sindicalismo brasileiro: da confrontação à cooperação conflitiva". São Paulo em Perspectiva. São Paulo: Fundação SEADE, 1995; MANGABEIRA, Wilma. Os dilemas do novo sindicalismo: democracia e política em Volta Redonda. Rio de Janeiro: Relume Dumará, 1993; VÉRAS DE OLIVEIRA, Roberto. A CUT somos nós... (A experiência-CUT e a questão da participação no imaginário dos militantes que atuam na Paraíba), João Pessoa, Dissertação (Mestrado em Ciências Sociais), UFPb, 1994; LADOSKY, Mario Henrique. A CUT no Governo Lula: da defesa da "liberdade e autonomia" à reforma sindical inconclusa. Tese (Doutorado em Sociologia). Faculdade de Filosofia, Letras e Ciências Humanas, USP, 2009; e SANTANA, Marco Aurélio. “Política e História em disputa: o ‘Novo Sindicalismo' e a idéia da ruptura com o passado”. In: JÁCOME RODRIGUES (org.). O novo sindicalismo vinte anos depois. 
uma linha de estudos no campo da História Social, suscitando novas interpretações acerca da experiência sindical do pré-64, colocando-se em franca oposição às teses weforttianas. Alguns destaques: French, Costa, Silva, Fontes, Santana, Fortes, Negro, ${ }^{39}$ entre outros. Silva e Costa, por exemplo, evidenciaram:

O populismo visto pelos trabalhadores era não raras vezes diferente da autoimagem construída pelas autoridades sobre seus próprios atos e discursos. Ao contrário da adesão cega e ativa, podia funcionar um pragmático realismo com elevado senso de cálculo em torno dos retornos e benefícios possíveis, impondo ao Estado e aos patrões concessões e deveres por meio de uma linguagem extraída dos próprios recursos retóricos populistas..$^{40}$

Muitas dessas abordagens tiveram como foco a atuação da militância comunista no período 1945-1964 no Sindicato dos Metalúrgicos do Rio de Janeiro, no Sindicato dos Metalúrgicos de São Bernardo do Campo e no Sindicato dos Químicos de São Paulo, buscando demonstrar atuações consistentes nos locais de trabalho e as pressões daí resultante sobre as direções sindical e do Partido. Essa releitura do sindicalismo do pré-64 se encontrou, naquele momento, com aquelas vertentes analíticas que, nos esforços de balanço do "novo sindicalismo" e do Sindicalismo CUT, buscaram considerar os elementos de ruptura e de continuidade. Nas palavras de Santana:

Decorridas duas décadas, o cenário sofreu enorme rearranjo, produzindo variações tanto no campo político-sindical quanto nas percepções dos atores. Resfriado o debate de posições, abre-se a possibilidade de revisão de algumas daquelas ideias que se constituíram em bases de apoio à construção e consolidação do que seria uma nova prática sindical. Este processo de revisão, tal como no momento de formação desse "sindicalismo de novo tipo", realiza-se tanto na academia quanto no seio do movimento sindical. ${ }^{41}$

39 FRENCH, John. O ABC dos operários: conflitos e alianças de classe em São Paulo, 1900-1950. São Paulo: Hucitec, 1995; COSTA, Hélio. Em busca da memória: comissão de fábrica, partido e sindicato no pósguerra. São Paulo: Scritta, 1995; Idem. "Trabalhadores, sindicatos e suas lutas em São Paulo (1943-1953)". In: FORTES, Alexandre et al (orgs.). Na luta por direitos: estudos recentes em História Social do Trabalho. Campinas: Editora da Unicamp, 1999; SILVA, Fernando Teixeira. A carga e a culpa: os operários das docas de Santos - Direitos e cultura de solidariedade (1937-1968). São Paulo: Hucitec; Santos: Prefeitura Municipal de Santos, 1995; Idem. "Direitos, política e trabalho no Porto de Santos". In: FORTES, Alexandre et al (orgs.). Na luta por direitos: estudos recentes em História Social do Trabalho. Campinas: Editora da Unicamp, 1999; FONTES, Paulo. Trabalhadores e cidadãos - Nitro Química: A fábrica e as lutas operárias nos anos 50. São Paulo: Annablume Editora, 1997; Idem. "Centenas de estopins acesos ao mesmo tempo: A greve dos 400 mil, piquetes e a organização dos trabalhadores em São Paulo (1957)". In: FORTES, Alexandre et al (orgs.). Na luta por direitos: estudos recentes em História Social do Trabalho; SANTANA Marco Aurélio. "Partido e militância sindical - a atuação comunista no Sindicato dos Metalúrgicos do Rio de Janeiro (1947/1964)". Revista de Sociologia e Política. Curitiba: UFPR, nº8, 1997; Idem. "Política e História em disputa: O 'Novo Sindicalismo' e a ideia da ruptura com o passado". In: JÁCOME RODRIGUES (org.). O novo sindicalismo vinte anos depois; FORTES, Alexandre et al. Revendo a legalização dos sindicatos: metalúrgicos de Porto Alegre (1931-1945). In: FORTES, Alexandre et al (orgs.). Na luta por direitos; e NEGRO. "Nas origens do 'Novo Sindicalismo"'.

40 SILVA, Fernando Teixeira; COSTA, Hélio. "Trabalhadores urbanos e populismo: um balanço dos estudos recentes". In: FERREIRA, J. (org.). O populismo e sua história: debate e crítica. Rio de Janeiro: Civilização Brasileira, p. 224-25, 2001.

41 SANTANA. "Política e História em disputa", p. 109-10. 


\section{Anos 1990: resistência propositiva ou capitulação?}

As implicações da globalização, da reestruturação produtiva, da onda neoliberal, da débâcle da experiência socialista foram contundentes para as dinâmicas do trabalho e as formas de ação coletiva dos trabalhadores. Entre os estudiosos do trabalho, tal contexto suscitou um debate acerca do futuro dos sindicatos, no mundo, na América Latina e no Brasil, a exemplo de: Caire; Visser; Zapata; Hyman; Stolovich; Castro e Wachendorfer; Mcllroy; Bhir; Bacon e Storey; Waterman; Munck e Waterman; Rodrigues; Beynon; Mouriaux,42 entre outros.

Nas análises internacionais, para uns, como Rodrigues, ${ }^{43}$ o diagnóstico apontou para um franco declínio sindical. Outros, como Bhir, ${ }^{44}$ realçaram o "fracasso" da luta operária diante da reestruturação do capital, associando-o, ao mesmo tempo, à postura "contra-revolucionária" ("modelo social-democrata") adotada pelos sindicatos e ao caráter localizado e isolado das novas práticas de auto-organização operária. Outros, ainda, a exemplo de Hyman; Beynon; Munck e Waterman, reconheceram que o sindicalismo passava por grave crise naquele contexto, mas admitiram estratégias de reação sindical. Entre estas: apoio a iniciativas de economia solidária e de desenvolvimento sustentável; maior sensibilidade para as temáticas de gênero e de juventude; incorporação de novas formas de internacionalismo; incorporação de demandas de segmentos de trabalhadores excluídos do mercado de trabalho; maior articulação com "movimentos populares"; valorização de formas organizativas horizontalizadas, entre outros.

No caso do sindicalismo brasileiro, embora tenha vivido, nos anos 1980, uma conjuntura contrastante com aquela dos países mais industrializados, na década seguinte passou a sofrer os efeitos da nova dinâmica capitalista mundial. A partir do governo Collor, com a adoção, no país, de políticas macroeconômicas neoliberais e a intensificação da reestruturação - implicando em privatizações de empresas estatais, reterritorializações de plantas industriais, na disseminação dos processos de terceirização, na adoção de sistemáticas medidas governamentais de

42 CAIRE, Guy. "Syndicalisme en crise". In : BIBES, Geneviève; MOURIAUX, René (ed.). Les syndicats eurpéens à l'épreuve. Paris: Presses de Sciences Politiques, 1990 ; VISSER, J. "Syndicalisme et désyndicalisation". In: Le mouvement social. Paris: Editions Ouvrières, $\mathrm{n}^{\circ}$ 162, jan/mar, 1993; ZAPATA, Francisco. "Crise do sindicalismo na América Latina?”. Dados - Revista de Ciências Sociais. Rio de Janeiro, vol. 37, n 1, 1994; HYMAN, Richard. "Changing Trade Union Identities and Strategies". In: HYMAN, R.; FERNER, A. (orgs.). Next Frontiers in European Industrial Relations. Oxford: Blackwell, 1994; STOLOVICH, L. "Reconversión productiva y respuesta syndical". In: NEFFA, Julio (org.). Nuevo paradigma productivo, flexibilidade y respuestas sindicais en América Latina. Buenos Aires: Asociación Trabajo y Sociedad, 1994; CASTRO, Maria Silvia Portela; WACHENDORFER, Achim (orgs.). Sindicalismo latinoamericano: entre la renovación y la resigniación. Venezuela: Nueva Sociedad; Brasil: Ildes-Fes, 1995; MCILROY, John. "O inverno do sindicalismo". In: ANTUNES (org.). Neoliberalismo, trabalho e sindicatos; BIHR, Alan. Da grande noite à alternativa: o movimento operário europeu em crise. São Paulo: Boitempo Editorial, 1998; BACON, N.; STOREY, J. "Individualism and Collectivism and the Changing Role of Trade Unions". In: The New Workplace and Trade Unionism. Critical Perspectives on Work and Organization. Londres: Routledge, 1996; WATERMAN, Peter. Globalization, Social Movements and the New Internationalisms. Londres: Mansell, 1998; MUNCK, Ronaldo; WATERMAN, Peter. Labour Worldwide in the Era of Globalisation: Alternative Union Models In The New World Order. Londres: Macmillan Press, 1999; RODRIGUES, Leôncio Martins. Destino do sindicalismo. São Paulo: Edusp/Fapesp, 1999; BEYNON, Huw. "O sindicalismo tem futuro no século XXI”. In: RAMALHO, José Ricardo; SANTANA, Marco Aurélio (orgs.). Além da fábrica: trabalhadores, sindicatos e a nova questão social. São Paulo: Boitempo, 2003; MOURIAUX, René. "O sindicalismo dos países industrializados em fins dos anos de 1970: efetivos, estruturas e estratégias". In: SANTANA, Marco Aurélio; RAMALHO, José Ricardo (orgs.). Além da fábrica.

43 RODRIGUES. Destino do sindicalismo, 1999.

44 BIHR. Da grande noite à alternativa, p. 64. 
desregulamentação das relações de trabalho etc. ${ }^{45}$-, produziu-se um quadro geral de desemprego, crescimento da informalidade, cortes de direitos e benefícios, queda nos níveis médios de remuneração, precarização das relações e condições de trabalho, com graves consequências para o movimento sindical.

Os sindicatos se viram diante de novos perfis de trabalhadores e novas posturas, seja da parte dos remanescentes do período anterior, seja da parte dos recém admitidos no mercado de trabalho, cuja motivação principal passou a ser "vestir a camisa da empresa" e preservar o emprego, mesmo que com redução de direitos. Ao mesmo tempo, tiveram que lidar com empregadores encorajados por uma correlação de forças mais favorável e com governos mais hostis à prática sindical, tal como ficou evidenciado no episódio da greve dos petroleiros de 1995, discutida em Rizek, ${ }^{46} \mathrm{o}$ ataque aos direitos sociais e trabalhistas em geral.

Quanto ao Sindicalismo CUT, mais em particular, durante toda a década atuou na defensiva, com sua capacidade de mobilização tendo sido fortemente afetada. Para completar o quadro, pela primeira vez, a CUT passou a contar com um adversário difícil de ser enfrentado no campo sindical. A Força Sindical, resultado de uma dissidência da CGT, tendo sido fundada em 1991, surgiu como um contraponto ao sindicalismo cutista, incorporando um discurso antirradical e a defesa de ser um "sindicalismo de resultados", de cunho "liberal" e "moderno" (Cardoso, 1992; Rodrigues e Cardoso, 1993; Nogueira, 1997; Cardoso, 1999a e 1999b; Tropia, 2004). ${ }^{47}$

Na reação cutista, as divergências internas ganharam novos ingredientes. O setor majoritário defendeu a formulação "resistência propositiva e disputa de hegemonia", visando dar base a um projeto de "reformas populares" a ser apresentado à sociedade pela CUT, acompanhado de sugestões de políticas industrial, agrícola e agrária, de desenvolvimento sustentável, de saúde e seguridade social, de educação. Os setores minoritários viram aí uma atitude "conciliatória". Ao invés, a CUT deveria reforçar seu compromisso com o socialismo. Predominou o foco na negociação e na participação institucional. ${ }^{48}$

Um momento marcante dessa nova estratégia se referiu à participação do sindicalismo cutista no episódio das câmaras setoriais, em especial do setor automotivo. ${ }^{49}$ Destacou-se, também, sua atuação nos diversos conselhos de políticas públicas, espaços de representação da sociedade e do Estado, previstos na Constituição de 1988, concebidos como conquistas da sociedade, fruto das lutas sindicais e políticas dos anos 1980. Nesse contexto, no seu interior, foi sendo gestada a ideia de um "sindicato cidadão", envolvendo três principais esferas de

45 Ver a respeito KREIN, José Dari. As tendências recentes nas relações de emprego no Brasil: 1990-2005. Tese (Doutorado em Economia). Campinas: Instituto de Economia, UNICAMP, 2007.

46 RIZEK, Cibele. A greve dos petroleiros. Praga, São Paulo: Editora Hucitec, 1998.

47 CARDOSO, Adalberto Moreira. "O pragmatismo impossível: origens da Força Sindical”. Novos Estudos. São Paulo, mar., 1992; Idem. Sindicatos, Trabalhadores e a coqueluche neoliberal: a Era Vargas acabou? Rio de Janeiro: FGV, 1999a; Idem. A trama da modernidade: pragmatismo sindical e democratização no Brasil. Rio de Janeiro: Editora Revan/IUPERJ, 1999b; RODRIGUES, Leôncio Martins; CARDOSO, Adalberto Moreira. A Força Sindical: uma análise sócio-política. São Paulo: Paz e Terra, 1993; NOGUEIRA, Arnaldo. A modernização conservadora do sindicalismo brasileiro: a experiência do Sindicato dos Metalúrgicos de São Paulo. São Paulo: Educ., 1997; TROPIA, Patrícia Vieira. O impacto da ideologia neoliberal no meio operário: um estudo sobre os metalúrgicos da cidade de São Paulo e a Força Sindical. Campinas, Tese (Doutorado em Ciências Sociais), UNICAMP, 2004.

48 VÉRAS DE OLIVEIRA, Roberto. "A Constituição de 1988, a questão da participação e o sindicalismo: problematizações”. In: KREIN, José Dari; SANTANA, Marco Aurélio; BIAVASCHI, Magda (orgs.). Vinte anos da Constituição Cidadã no Brasil. São Paulo: LTr, 2010.

49 OLIVEIRA, Francisco de. Apocalypse Now: "O ‘Coração das Trevas' do neoliberalismo”. São Paulo, mimeo., 1997. 
ação: a centralidade das lutas em defesa dos direitos; a participação institucional com vistas a influir na formulação e acompanhamento das políticas públicas; e a execução de políticas públicas, por meio do desenvolvimento de projetos cooperativos e da oferta de serviços, sob financiamento público. ${ }^{50}$

Os estudos focados nas condições e formas de trabalho e nos novos perfis dos trabalhadores (realçando aspectos técnicos, organizacionais, institucionais, políticos, culturais, subjetivos etc.) assumiram proeminência como tema de pesquisa. ${ }^{11}$ Entretanto, estes não cessaram. Não só foi preservado como um campo de pesquisa social, apesar de certo encolhimento, como, acompanhando a diversificação da agenda sindical, passou a incorporar novas temáticas (gênero, questão racial, territórios, desenvolvimento local, movimentos sociais, questão ecológica, políticas públicas etc.).

Dentre os que se mantiveram focados nos estudos sindicais, especialmente voltados à trajetória cutista, um campo mais fiel ao referencial marxista, ${ }^{52}$ convergindo com a perspectiva do setor minoritário do Sindicalismo CUT, interpretou a orientação dada pelo setor majoritário como uma capitulação diante do ideário neoliberal. Foi esse, com diferenças de ênfases, o eixo das análises de Boito Jr; Alves; Galvão; Antunes; Cavalcante; Praun, Codas, entre outras. ${ }^{53} \mathrm{Na}$ síntese de Alves:

Para Antunes, o aumento das "greves por empresa" no decorrer dos anos 80 indicava, no seio do movimento sindical brasileiro, o avanço da tendência do "sindicalismo de resultados" (o "sindicalismo de resultados" assumiria uma expressão política clara com a criação da Força Sindical, em 1991). Por outro lado, no interior da própria CUT, sob a era neoliberal, desdobrar-se-ia uma tendência similar, de cariz neocorporativo, com o sindicalismo de participação, que privilegia estratégias propositivas; um novo sindicalismo, cada vez mais defensivo, disposto a incluir, em sua pauta de resistência, a parceria com o capital. Nos anos 90, sob o novo complexo de reestruturação produtiva, tender-se-ia a privilegiar, cada vez mais, as "greves por empresas",

50 VÉRAS DE OLIVEIRA, Roberto. Sindicalismo e democracia no Brasil: do novo sindicalismo ao sindicato cidadão. São Paulo: Annablume Editora, 2011.

51 Ver, por exemplo: CASTRO, Nadya; GUIMARÃES, Sérgio. "Competitividade, tecnologia e organização do trabalho: a petroquímica brasileira nos anos 9o". In: LEITE, Marcia; SILVA, R. (orgs.). Modernização tecnológica, relações de trabalho e práticas de resistência. São Paulo: IGLU/ILDES/LABOR, 1991; CASTRO, Nadya. "Modernização e trabalho no complexo automotivo brasileiro: reestruturação industrial ou japanização de ocasião?”. Novos Estudos Cebrap. São Paulo: CEBRAP, n 37, novembro, 1993; CASTRO, Nadya (org.). A máquina e o equilibrista: inovações na indústria automobilística brasileira. Rio de Janeiro: Paz e Terra, 1995 e LEITE, Márcia de Paula. O futuro do trabalho: novas tecnologias e subjetividade operária. São Paulo: Scritta Editora, 1994.

52 Além de uma referência mais presente da obra de próprio Marx, são citados com frequência textos de Georg Lukacs, Louis Althusser, Nicos Poulantzas, Istvan Meszaros, Perry Anderson, entre outros.

53 BOITO Jr, Armando. "De volta para o novo corporativismo - a trajetória política do sindicalismo brasileiro”. São Paulo em Perspectiva. São Paulo: Fundação Seade, nº 3, 1994; Idem. Política neoliberal e sindicalismo no Brasil. São Paulo: Xamã, 1999; ALVES, Giovanni. "Do 'Novo Sindicalismo' à 'Concertação Social': ascensão (e crise) do sindicalismo no Brasil (1978-1998)". Revista de Sociologia e Política. Curitiba, nov., 2000; GALVÃO, Andréia. Participação e fragmentação: a prática sindical dos metalúrgicos do $A B C$ nos anos 90. Dissertação (Mestrado em Sociologia). Campinas: IFCH/Unicamp, 1996; Idem. "Do coletivo ao setor, do setor à empresa: a trajetória do 'novo sindicalismo' metalúrgico nos anos 90". In: JÁCOME RODRIGUES (org.). O novo sindicalismo vinte anos depois; ANTUNES, Ricardo. "Trabalho, reestruturação produtiva e algumas repercussões no sindicalismo brasileiro". In: ANTUNES (org.). Neoliberalismo, trabalho e sindicatos; CAVALCANTE, Sávio. Sindicalismo e privatização das telecomunicações. São Paulo: Expressão Popular, 2009; PRAUN, Luci. "Sindicalismo metalúrgico no $A B C$ paulista: da contestação à parceria”. In: SOUZA, Davisson Cangussu; TRÓPIA, Patrícia Vieira (orgs.). Sindicatos metalúrgicos no Brasil contemporâneo. Belo Horizonte: Fino Traço, 2012; CODAS, Gustavo. "O ‘rapto' da vanguarda”. São Paulo em Perspectiva (Movimento Operário e Sindical), vol. 12, n¹, 1998. 
demonstrando o predomínio - inclusive no interior do sindicalismo da CUT - da política do "sindicalismo de resultados". 54

Em uma outra direção, conformando um perfil teórico-metodológico menos homogêneo, desenvolveram-se diversos outros estudos sobre o tema. São exemplos: Castro e Guimarães; Castro; Castro e Comin; Bresciani; Martins; Jácome Rodrigues; Jácome Rodrigues e Ramalho; Zanetti; Leite; Ramalho; Ramalho e Santana; Ramalho, Jácome Rodrigues e Santana; Ramalho e Jácome Rodrigues; Laranjeira; Blass; Oliveira; Pessanha e Morel; Pessanha; Nogueira; Negro; Santana; Ferraz; Véras de Oliveira; Costa; Campos; Bridi; Bridi e Véras de Oliveira; Bridi; Pereira, ${ }^{55}$ entre outros. Não obstante as diferenças, tiveram em comum a

54 ALVES. Do “'Novo Sindicalismo' à 'Concertação Social”", p. 115.

55 CASTRO, Nadya; GUIMARÃES, Sérgio. "Trabalho, sindicalismo e reconversão industrial no Brasil nos anos 90”. Lua Nova. São Paulo, n²2, dezembro, 1990; CASTRO, Nadya. "Reestruturação produtiva, novas institucionalidades e negociação da flexibilidade". São Paulo em Perspectiva. São Paulo, vol. 11, n 1, p. 3-9, 1997.

CASTRO, Nadya; COMIN, Álvaro. "As novas esferas de regulação do trabalho e o dilema sindical”. São Paulo em Perspectiva (Movimento Operário e Sindical), vol. 12, n 1, 1998; BRESCIANI, Luis Paulo. Da resistência à contratação: tecnologia, trabalho e ação sindical no Brasil. Brasília: Sesi, 1994; MARTINS, Heloísa H. T. de Souza. "Os dilemas do movimento sindical em face da terceirização". In: MARTINS, Heloísa; RAMALHO, José Ricardo (orgs.). Terceirização: diversidade e negociação no mundo do trabalho. São Paulo: Ed. Hucitec/ Cedi-Nets, 1994; JACOME RODRIGUES, Iram. "A questão da organização por local de trabalho: dilemas e perspectivas do sindicalismo - CUT”. In: MARTINS; RAMALHO (orgs.). Terceirização: diversidade e negociação no mundo do trabalho; Idem. "Perspectiva do sindicalismo brasileiro nos anos 90: a experiência da Central Única dos Trabalhadores”. In: DINIZ; LOPES; PRANDI (orgs.). O Brasil no rastro da crise; Idem. As comissões de empresa e o movimento sindical. In: BOITO JR. (org.). O sindicalismo brasileiro nos anos 80; Idem. "Liberdade sindical e representação no local de trabalho: o dilema do sindicalismo no Brasil”. In: FERNANDES, Reynaldo (org.). O Trabalho no Brasil no limiar do século XXI. São Paulo: LTR, 1995; Idem. Sindicalismo e política: a trajetória da CUT. São Paulo: Scritta; FAPESP, 1997; Idem. "Sindicalismo, emprego e relações de trabalho na indústria automobilística". In: ANTUNES (org.). Neoliberalismo, trabalho e sindicatos; Idem. "A trajetória do novo sindicalismo". In: JÁCOME RODRIGUES (org.). O novo sindicalismo vinte anos depois; Idem. "Relações de trabalho no ABC paulista na década de 1990". In: SANTANA, Marco Aurélio, RAMALHO, José Ricardo (orgs.). Além da fábrica; JÁCOME RODRIGUES, Iram; RAMALHO, José Ricardo. "Sindicalismo na Inglaterra e no Brasil: estratégias diante das novas formas de gestão da produção". São Paulo em Perspectiva. São Paulo: Fundação Seade, vol. 12, n 1, 1998; Idem. "Sindicato, desenvolvimento e trabalho: crise econômica e ação política no ABC”. Caderno do CRH, vol. 26, n 68, Salvador, 2013; ZANETTI, Lorenzo. O novo sindicalismo: características, impasses e desafios. Rio de Janeiro: FASE, 1995; LEITE, Márcia de Paula. "Reestruturação produtiva e sindicatos: o paradoxo da modernidade". In: LEITE, Márcia (org.). O trabalho em movimento. Campinas: Papirus, 1997; RAMALHO, José Ricardo. Precarização do trabalho e impasses da organização coletiva no Brasil. In: ANTUNES, Ricardo (org.). Neoliberalismo, trabalho e sindicatos; Idem. "Organização sindical e a instalação de novas fábricas do setor automobilístico - o caso do sul Fluminense". In: JÁCOME RODRIGUES (org.). O novo sindicalismo vinte anos depois; Idem. "Trabalho e sindicato: posições em debate na Sociologia hoje”. Dados, vol. 43, n 4, Rio de Janeiro, IUPERJ; RAMALHO, José Ricardo; SANTANA, Marco. “Trabalhadores, sindicatos e a nova questão social”. In: RAMALHO, José Ricardo; SANTANA, Marco Aurélio (orgs.). Além da fábrica; RAMALHO, José Ricardo; JÁCOME RODRIGUES, Iram; SANTANA, Marco Aurélio. “Desenvolvimento e região: novas questões para a pauta sindical?". In: PORTO, Maria Stela Grossi; DWYER, Tom (orgs.). Sociologia em transformação - pesquisa social no século XXI. Porto Alegre: Tomo Editorial, 2006; RAMALHO, José Ricardo; JÁCOME RODRIGUES, Iram. "Sindicato, crise econômica e estratégias regionais: novas dimensões da participação política no ABC paulista". Caderno CRH (UFBA. Impresso), vol. 23, p. 339351, 2010; LARANGEIRA, Sônia. "Há lugar para o sindicalismo na sociedade pós-industrial? Aspectos do debate internacional”. São Paulo em Perspectiva (Movimento Operário e Sindical), vol. 12, n 1, 1998; BLASS, Leila Maria da Silva. "Alcance e limites da reestruturação negociada". São Paulo em Perspectiva (Movimento Operário e Sindical), vol. 12, n 1, 1998; Idem. "Novo Sindicalismo: persistência e continuidade”. In: JÁCOME RODRIGUES (org.). O novo sindicalismo vinte anos depois; Idem. De volta ao futuro: o discurso empresarial e sindical no fim da autolatina. São Paulo: Educ., 2001; OLIVEIRA, Marco Antônio de. "Notas sobre a crise do novo sindicalismo brasileiro". São Paulo em Perspectiva (Movimento Operário e Sindical), vol.12, $n^{\circ} 1$, 1998; PESSANHA, Elina; MOREL, Regina. "Mudanças recentes no modelo de relações de trabalho no Brasil e novo sindicalismo". In: JÁCOME RODRIGUES (org.). O novo sindicalismo vinte anos depois; PESSANHA, Elina. Operários navais: trabalho, sindicalismo e política na indústria naval do Rio de Janeiro. Rio de Janeiro: 7 Letras, 2012; NOGUEIRA, Arnaldo. "Emergência e crise do Novo Sindicalismo no setor público brasileiro". In: JÁCOME RODRIGUES (org.). O novo sindicalismo vinte anos depois; Idem. A liberdade desfigurada - a trajetória do 
preocupação de buscar apreender a nova realidade do mundo do trabalho e das práticas coletivas dos trabalhadores como campos de possibilidades abertas, predispondo-se à incorporação de novos elementos de análise, do lado dos esforços teóricos, e à valorização dos esforços de inovação estratégica, do lado das experiências empíricas estudadas. Em tais perspectivas, a pesquisa empírica adquire maior relevância, seja com ênfase qualitativa ou quantitativa. ${ }^{56}$ Para uma indicação, veja-se o argumento de Ramalho e Santana:

Concretamente, o que se teve foi que o pano de fundo que conjugava desemprego e precariedade no trabalho fez também com que os sindicatos mudassem as pautas de reivindicação. Se nos anos 1980 a questão econômico-salarial tinha prioridade, nos anos 1990 (principalmente em sua segunda metade), a temática da garantia do emprego e as tentativas de combate ao desemprego assumem o primeiro plano. Além disso, os sindicatos buscaram outras alternativas que ampliassem seu escopo de ação, contribuindo para a consolidação de novas institucionalidades (Castro, 1997). Isso ocorreu em uma lógica que foi desde o sindicato de base até as estruturas intersindicais. Nesse sentido, as centrais sindicais de maior relevo acabaram por se envolver em projetos os mais variados em termos de formação profissional, constituição de cooperativas de trabalho e intermediação entre trabalhador e emprego, através de agências e centros de solidariedade. Em muitos casos, esse envolvimento se deu de forma defensiva, em detrimento de movimentos de mobilização dos trabalhadores. No entanto, constata-se que o movimento sindical tem feito um significativo esforço para buscar fórmulas alternativas em face da necessidade de negociar a reorganização da produção, preservando postos de trabalho e salários e insistindo em uma maior participação dos trabalhadores nas decisões das empresas. ${ }^{57}$

sindicalismo no setor público brasileiro. São Paulo: Editora Expressão Popular, 2005; NEGRO, Antonio Luigi. "Nas origens do "Novo Sindicalismo": o maio de 1959, 68 e 78 na indústria automobilística". In: JÁCOME RODRIGUES (org.). O novo sindicalismo vinte anos depois; SANTANA, Marco Aurélio. "Política e história em disputa: o "Novo Sindicalismo" e a idéia da ruptura com o passado". In: JÁCOME RODRIGUES (org.). O novo sindicalismo vinte anos depois; Idem. "Trabalho, trabalhadores e sindicatos em meio ao vendaval contemporâneo". Dados. Rio de Janeiro: IUPERJ, vol. 43, no 2, 2000; Idem. "O sindicalismo brasileiro nos anos 1980/2000: do ressurgimento à reorientação". Cadernos Adenauer. Rio de Janeiro: Fundação Konrad Adenauer.

FERRAZ, Marcos. Da cidadania salarial à Agência de Desenvolvimento Solidário: o Sindicalismo-CUT e os desafios para inventar uma nova cidadania. São Paulo. Tese (Doutorado em Sociologia), FFLCH/USP, 2005; Idem. "Do confronto à negociação: a CUT na passagem dos anos 1990 ou equívoco teórico?”. In: ARAÚJO, Silvia; BRIDI, Maria Aparecida; FERRAZ, Marcos (orgs.). O sindicalismo equilibrista: entre o continuísmo e as novas práticas. Curitiba: UFPR/SCHLA, 2006; VÉRAS DE OLIVEIRA, Roberto. "O sindicalismo e a questão democrática na história recente do Brasil”. In: OLIVEIRA, Francisco de; RIZEK, Cibele Saliba (orgs.). A era da Indeterminação. São Paulo: Boitempo, 2007; Idem. Sindicalismo e democracia no Brasil: do Novo Sindicalismo ao Sindicato Cidadão. São Paulo: Annablume Editora, 2011; COSTA, Cândida. Nas malhas da instabilidade: os trabalhadores públicos em um cenário de mudanças. São Luís: EDUFMA, 2008; CAMPOS, Anderson. Juventude e ação sindical: crítica ao trabalho indecente. Rio de Janeiro: Letra e Imagem, 2010; PESSANHA, Elina. Operários navais: trabalho, sindicalismo e política na indústria naval do Rio de Janeiro. Rio de Janeiro: 7 Letras, 2012; BRIDI, Maria Aparecida. "O Sindicato dos Metalúrgicos no Paraná no compasso das mudanças no trabalho". In: SOUZA; TRÓPIA (orgs.). Sindicatos Metalúrgicos no Brasil contemporâneo; BRIDI, Maria Aparecida; VÉRAS DE OLIVEIRA, Roberto. O protagonismo dos trabalhadores no local de trabalho: 25 anos de história da Comissão de Fábrica na Volvo. Curitiba: SK Editora, 2012 e PEREIRA, Sérgio Martins. Sindicalismo e privatização: o caso da Companhia Siderúrgica Nacional. São Luiz: Edufma, 2012.

56 O caráter heterogêneo desse "campo" (se se pode falar assim) envolve uma maior abertura para compor influências teórico-metodológicas diversas, que passam por perspectivas tão diferentes quanto E. P. Thompson, Antonio Gramsci, Pierre Bourdieu, Karl Polanyi, Mark Granovetter, Robert Castel, Michael Burawoy, Richard Sennett, Erik Olin Wright, David Harvey, Alain Lipietz, Gösta Esping-Andersen, Claus Offe, entre muitos outros.

57 RAMALHO e SANTANA. “Trabalhadores, sindicatos e a nova questão social”, p. 32-33. 
Foi assim que os estudos com foco no tema sindical, pressionados pelo refluxo político dos trabalhadores, ultrapassaram os áridos anos 1990, tendo chegado aos anos 2000 sinalizando um novo fôlego. No entanto, a diversidade interpretativa do campo sociológico acerca do sindicalismo no país ganhou novos elementos a partir da eleição de Lula para a presidência da República, especialmente sobre o posicionamento da CUT frente ao novo Governo e quanto à emergência de novas correntes sindicais.

\section{Com a eleição de Lula, quais os novos desafios do sindicalismo?}

O Governo Lula criou na militância cutista a expectativa de uma clara ruptura com o passado, especialmente com o período imediatamente anterior de predomínio das políticas neoliberais. Entretanto, não obstante a associação entre a candidatura de Lula, as lutas democrático-populares das últimas décadas e o Sindicalismo CUT, o processo eleitoral e a constituição do novo governo estiveram sempre marcados por um caráter contraditório e complexo, com evidentes dificuldades em se efetivarem as esperadas rupturas.

Sob tal situação, entre os militantes identificados com a CUT, prevaleceu a cautela, resvalando muitas vezes para uma postura ambígua e vacilante. Procurou participar dos espaços e canais criados em nome de um novo patamar de diálogo social, a exemplo do Conselho Nacional de Desenvolvimento Econômico e Social - CDES e do Fórum Nacional do Trabalho - FNT. Buscou atuar propositivamente no campo das políticas sociais, a exemplo do Conselho Nacional de Seguridade Social, que passou a gerir o programa Fome Zero. Evitou ações que pudessem produzir confrontos com o Governo, como greves e manifestações mais amplas (o que teve particular repercussão por ocasião do encaminhamento da Reforma da Previdência). Ensaiou críticas pontuais a aspectos da política econômica. Esforçouse para evitar a pecha de "sindicalismo oficial". ${ }^{58}$

Um tema em evidência no primeiro mandato de Lula foi o da Reforma Sindical, que, a despeito da forte expectativa criada, não logrou êxito. Analisando o resultado das Conferências Estaduais do Trabalho, que precederam o debate no FNT, Horn ${ }^{59}$ constatou que a taxa geral de consenso foi de apenas $27,3 \%$, antecipando as dificuldades que viriam. Com a falta do consenso esperado no Fórum, a proposta encaminhada pelo MTE ao Congresso Nacional - a PEC 369/05 e o Anteprojeto de Lei de Relações Sindicais (ALRS) - foram bombardeados por todos os lados. Para Ladosky ${ }^{60}$ (2009), além das reações das chamadas "forças conservadoras", as críticas vieram também de acadêmicos, juristas, políticos,

58 Desde janeiro de 2003, foram vários os sindicalistas ligados à CUT que assumiram cargos de destaque no Governo, principalmente no primeiro mandato de Lula. Além do próprio presidente, um dos fundadores da CUT, sete ex-dirigentes sindicais assumiram cargos de ministro: Antonio Palocci (Fazenda), Jaques Wagner (Trabalho), Luis Gushiken (Secretaria de Comunicação), Luiz Dulci (Secretaria Geral), Ricardo Berzoini (Previdência Social), Miguel Rossetto (Desenvolvimento Agrário) e Olívio Dutra (Cidades). Vários sindicalistas ocuparam cargos de alto escalão em ministérios e órgãos federais. Além desses, ex-dirigentes sindicais assumiram postos de comando em conselhos de estatais e de fundos de pensão, como na Previ, Petros, Sebrae, Sesi e Itaipu, bem como cargos de relevância no segundo e terceiro escalões dos ministérios.

59 HORN, Carlos Henrique. "A difícil busca de um consenso para a mudança nas Conferências Estaduais do Trabalho". Democracia e Mundo do Trabalho, Porto Alegre, vol. 1, n 1, 2005.

60 Idem, 2009. 
empresários, da mídia e, até, de sindicalistas. As centrais divergiram publicamente, principalmente em relação à constituição das organizações de direção nacional e ao fim do imposto sindical e da unicidade sindical. A CUT não teve uma atuação coesa nem dentro da Articulação Sindical, sua corrente majoritária.

As críticas, embora tímidas (focadas na contestação da Reforma da Previdência e na política de juros altos), diminuíram com a melhoria dos indicadores de crescimento da indústria, com a formalização do emprego e a queda das taxas de desemprego. Essa postura alimentou as críticas internas, da parte das correntes mais à esquerda, de ausência de independência e adesão acrítica ao Governo Lula. ${ }^{61}$

Outro ponto que evidenciou as divergências entre a CUT e as demais centrais sindicais ocorreu ainda no primeiro mandato de Lula, quando do episódio do chamado "mensalão". O caso envolveu figuras centrais do PT, do Governo e da base aliada, incluindo ex-lideranças sindicais ligadas à CUT e que haviam sido deslocadas para cargos no Governo, as quais foram acusadas de compra de apoio político de parlamentares. Tais denúncias e os processos e campanhas que daí derivaram tiveram forte impacto no cenário político do país, produzindo exaltados posicionamentos a favor e contra os acusados. No que se refere ao campo sindical, enquanto que na CUT prevaleceu uma posição de cautela e de defesa dos acusados, tanto a Força Sindical, à direita, como a nova corrente sindical, a CONLUTAS (que resulta de dissidência da CUT especialmente a partir de divergências sobre o tema da Reforma Sindical), à esquerda, destacaram-se em posicionamentos críticos mais contundentes, reforçando o tom acusatório.

A combinação do acirramento das divergências internas, sobretudo quanto ao posicionamento da CUT frente ao governo, com a aprovação da proposta de reconhecimento das centrais, ${ }^{62}$ levou à ruptura da parte de algumas correntes minoritárias e à constituição de novas entidades intersindicais: a CONLUTAS, em 2004, sob hegemonia do Partido Socialista dos Trabalhadores Unificado (PSTU), ${ }^{63}$ e a INTERSINDICAL, em 2005, organizada sob influência de militantes do Partido Socialismo e Liberdade (PSOL). ${ }^{64}$

Além da CUT, criada em 1983, da Central Geral dos Trabalhadores Brasileiros (CGTB), em 1983, ${ }^{65}$ da Força Sindical, em 1991, da CONLUTAS, em 2004 e da INTERSINDICAL, em 2005, foram constituídas: a Nova Central Sindical (NCST), em 2005, a partir das confederações mais tradicionais de trabalhadores de distintos setores; da União Geral dos Trabalhadores (UGT), em 2007, a partir da fusão entre a Confederação Geral dos Trabalhadores (CGT), a Central Autônoma dos Trabalhadores (CAT) e a Social Democracia Sindical (SDS); da Central dos Trabalhadores e das Trabalhadoras do Brasil (CTB), em 2007, a partir da Corrente Sindical Classista (CSC), ligada ao Partido Comunista do Brasil e até então atuante na CUT. ${ }^{66}$

61 ARAÚJO, Ângela; VÉRAS DE OLIVEIRA, Roberto. “El sindicalismo brasileño en la Era de Lula". Revista Latinoamericana de Estudios del Trabajo, vol. 5, p. 83-112, 2011.

62 Que concedeu às centrais a atribuição de coordenar as políticas gerais das entidades a elas filiadas e de atuar em nome do conjunto dos trabalhadores, sendo sua representação, nos fóruns e comissões de negociação tripartite, proporcional ao número de filiados. Ao mesmo tempo garantiu financiamento público às centrais que, atendendo os requisitos da lei, venham a ser reconhecidas pelo Estado.

63 Formado por dissidência do PT, em 1994.

64 A INTERSINDICAL não se propôs imediatamente a se organizar como uma nova central, pois parte dos seus membros continuaram vinculados à CUT (Galvão, 2009).

65 Sendo criada, em 1983, como CONCLAT, convertida, em 1986, na CGT, e renomeada como CGTB, em 1994.

66 Em 2008, no segundo congresso da INTERSINDICAL, esta se dividiu entre os que desejavam se unir à CONLUTAS, para formar uma nova central sindical, e os que pretendiam se manter independentes. Dali em diante, passaram a existir duas INTERSINDICAIS, uma reunindo os segmentos ligados ao PSOL 
À já marcante pulverização da organização sindical na base (sindicatos), somou-se uma fragmentação também da cúpula (centrais), principalmente em detrimento da CUT. Mas, ao mesmo tempo, do ponto de vista da ação, produziramse nesse novo contexto muitas convergências entre as diversas centrais. Exemplo disso foram as seis Marchas à Brasília pela valorização do salário mínimo, ocorridas entre 2004 e 2009 e outras pautas em torno da manutenção do emprego, redução da jornada de trabalho para 40 horas, mudanças na política de juros do governo federal, fim do fator previdenciário, entre outras. Mas divergências também se apresentaram, seja da parte da CONLUTAS, em vista de sua clara oposição ao Governo, seja entre as demais centrais, a exemplo do que ocorreu, no início de 2009, quando a CUT e a Força Sindical divergiram publicamente quanto à orientação para o enfrentamento da crise financeira global irradiada após a quebra do Banco Lehman Brothers, em 2008.

No que se refere aos estudos sindicais, novamente as análises foram contaminadas pelas posições sob disputas políticas. Especialmente, a perspectiva de análise sobre a experiência de governo inaugurada com a primeira eleição de Lula passou a exercer um peso decisivo no modo de se avaliar a atuação sindical no novo contexto.

Em um campo, teve continuidade uma linha de abordagem que vinha identificando as posições majoritárias da CUT com um longo processo de degeneração burocrática, de substituição da luta de classes pela conciliação de classes e uma crescente incapacidade de oposição à ideologia neoliberal. Com a eleição de Lula, tendo este como um Governo de continuidade neoliberal, essa incapacidade da corrente cutista estaria sendo ainda mais evidenciada, com esta atuando como um sindicalismo "chapa branca" e dento de um marco políticoideológico que inviabiliza sua constituição como força de oposição ao projeto neoliberal. Isso explicaria as defecções sofridas pela CUT. Alves; Antunes; Galvão; Marcelino; Matos; Silva; Perondi; Carvalho, ${ }^{67}$ entre outros, expressam esse veio interpretativo, mesmo com distinções.

(que defendem articulação com a CONLUTAS) e outra ligada ao PCB e "Independentes". Entretanto, o congresso convocado, em 2010, para unificar a CONLUTAS, a INTERSINDICAL e os "Independentes" não se efetivou. Na ocasião, a CONLUTAS virou Central Sindical e Popular CONLUTAS (CSP-CONLUTAS). Além dessas, outras articulações sindicais, de menor expressão política, têm sido criadas recentemente, com vistas ao reconhecimento enquanto Centrais Sindicais (sem que, para tanto, tenham alcançado ainda os requisitos estabelecidos na Lei 11.648/08): a Central Sindical de Profissionais (CSP), resultante de uma cisão da CGTB, tendo sido denominada Central dos Sindicatos Brasileiros (CSB), em 2012, para se diferenciar da CSP CONLUTAS; a União Sindical dos Trabalhadores (UST); a Central do Brasil Democrática de Trabalhadores - CBDT Nacional; a Central Nacional Sindical dos Profissionais em Geral (CENASP); e a Central Unificada dos Profissionais Servidores Públicos do Brasil.

67 ALVES. "Do 'Novo Sindicalismo' à 'Concertação Social”'; ANTUNES, Ricardo. "Reforma sindical é um desastre para trabalhadores". In: Correio da Cidadania, 23 de março de 2005; Idem. "De Vargas a Lula: caminhos e descaminhos da Legislação Trabalhista no Brasil". Pegada, vol. 7, n², 2006; Idem. "Legalização do imposto sindical reforçará ‘neopeleguismo' e 'neoestatismo”'. Correio da Cidadania, 27 de março de 2008. GALVÃO, Andreia. "O movimento sindical frente ao governo Lula: dilemas, desafios e paradoxos". Outubro - Revista do Instituto de Estudos Socialistas, n’ 14, 2006; Idem. Neoliberalismo e reforma trabalhista no Brasil. Rio de Janeiro: Renavan/Fapesp, 2007; Idem. "De 'laboratório' das relações de trabalho a formulador da política nacional: o Sindicato dos Metalúrgicos do ABC paulista”. In: SOUZA; TRÓPIA (orgs.). Sindicatos metalúrgicos no Brasil contemporâneo; MARCELINO, Paula. Terceirização e ação sindical. A singularidade da reestruturação do capital no Brasil. Tese (Doutorado em Ciências Sociais). Campinas: UNICAMP, 2008; MATOS, Marcelo Badaró. Trabalhadores e sindicatos no Brasil. São Paulo: Expressão Popular, 2009; SILVA, Sidartha Soria e. Intersecção de classes: fundos de pensão e sindicalismo no Brasil. Campinas, Tese (Doutorado em Sociologia), UNICAMP, 2011 e PERONDI, Eduardo. Conciliação e precarização: a política trabalhista do governo Lula (2003-2010). Florianópolis: UFSC, 2011; CARVALHO, Guilherme. A representação da CUT nos governos Lula (2003-2010). Tese (Doutorado em Sociologia). Universidade Estadual Paulista (UNESP), 2012. 
Em outra vertente, segue uma linha de interpretações procurando apreender, da prática sindical e, agora, também do novo quadro político, novas possibilidades e limitações. Por meio dessas abordagens (também com acentos diversos), valorizam-se os processos empíricos das disputas de classes, as experiências de governo e sindical como espaços em disputa (especialmente, no contexto tratado), as novas iniciativas como possibilidades em aberto (portanto, sendo impositivo seu acompanhamento, com abordagens que atribuem maior importância epistemológica à pesquisa empírica). São exemplos: Jácome Rodrigues, Ramalho e Conceição; Ladosky; Krein; Véras de Oliveira; Araújo e Véras de Oliveira; Ramalho e Jácome Rodrigues; Forte; Silverman. ${ }^{68}$

Por essa via, têm sido evidenciados os ganhos sociais do período, ao mesmo tempo em que se reconhece, nessas conquistas, um peso às lutas sindicais. Como exemplo, considera-se que a pressão exercida pelas centrais sindicais teve influência para a correção da tabela do imposto de renda, o aumento de recursos destinados à agricultura familiar e o persistente aumento do salário mínimo. Admite-se, também, que as negociações coletivas, em importantes setores da economia, foram espaços de recuperações de perdas anteriores. Mas, por outro lado, avalia-se que, apesar de um contexto mais favorável econômica e politicamente, o sindicalismo não tem sido capaz de aproveitá-lo de modo a produzir mudanças mais estruturais nas condições e relações de trabalho no país. Pois, se no período anterior o movimento sindical foi colocado em uma posição de resistência defensiva, na Era Lula/Dilma estaria prevalecendo, de um lado, uma atitude de expectativa frente às iniciativas do Governo e, de outro, uma postura de oposição política ao Governo, sem que a esta corresponda uma capacidade maior de mobilização. Na avaliação de Ângela e Véras de Oliveira, ${ }^{69}$ comparando-se o momento atual com os contextos dos anos 1990 e, principalmente, dos anos 1980, sobressai o fato de que o sindicalismo perdeu em muito a condição de protagonista político, com as centrais sindicais não conseguindo, com suas demandas, pautar o debate político do país. No máximo, administraram uma agenda de negociações diretas (com certos ganhos) e uma outra (nem sempre de modo associado à primeira) voltada à participação em espaços institucionais públicos e sindicais.

Um balanço mais amplo e sistemático sobre a atuação sindical na Era Lula/ Dilma, no entanto, ainda está por ser feito, inclusive em razão desse período não ter sido concluído. Algumas interpretações e reflexões, envolvendo diferentes dimensões das dinâmicas social, econômica e política, referidas ao contexto atual, desafiam os estudos sobre trabalho e sindicalismo no Brasil à incorporação de

68 JÁCOME RODRIGUES, Iram; RAMALHO, José Ricardo; CONCEIÇÃO, Jefferson José da. "Relações de trabalho e sindicato no primeiro governo Lula (2003-2006)". Ciência e Cultura (SBPC), vol. 60, p. 5457, 2008; LADOSKY, Mario Henrique. A CUT no Governo Lula: da defesa da "liberdade e autonomia" à reforma sindical inconclusa Tese (Doutorado em Sociologia). São Paulo: USP, 2009; KREIN, José Dari. "A crise e suas implicações para o sindicalismo e a negociação coletiva". In: ROCHA, Eduardo (org.). 100 Anos de movimento sindical no Brasil: balanço histórico e desafios futuros. Brasília: Editorial Abaré, 2010a; Idem. "Ação sindical em espaços institucionais em perspectiva histórica recente". In: KREIN, José Dari; SANTANA, Marco Aurelio; BIAVASCHI, Magda (orgs.). Vinte anos de Constituição Cidadã no Brasil. São Paulo: LTr., 2010b; VÉRAS DE OLIVEIRA. "A Constituição de 1988'; Idem. "Suape em construção, peões em luta: o novo desenvolvimento e os conflitos do trabalho". Caderno CRH (UFBA. Impresso), vol. 26, p. 233-252, 2013. ARAÚJO, Ângela; VÉRAS DE OLIVEIRA, Roberto. "El sindicalismo brasileño en la Era de Lula", p. 83-112; RAMALHO, José Ricardo; JÁCOME RODRIGUES, Iram. "Sindicato, desenvolvimento e trabalho: crise econômica e ação política no ABC". Caderno do CRH, vol. 26, no 68, Salvador, 2013; e FORTE, Fernanda. Os dilemas da CUT no início do século XXI: rumo a uma nova institucionalização sindical? Coimbra. Tese (Doutorado em Sociologia), Universidade de Coimbra, 2013; SILVERMAN, Jana. Reformas sindicais e a inserção política do movimento sindical no Cone Sul sob governos progressistas: uma analise dos casos do Brasil e Uruguai. Campinas, Tese (Doutorado em Economia) UNICAMP, 2014.

69 ARAÚJO e VÉRAS DE OLIVEIRA. "El sindicalismo brasileño en la Era de Lula". 
novos temas e questões. Apenas como ilustração, aqui destacamos as abordagens de Jessé Souza, Eli Diniz, André Singer, Ruy Braga, Márcio Pochmann, entre outros, ${ }^{70}$ que têm posto em discussão, seja em sentido propositivo ou crítico, noções como ralé brasileira, novo desenvolvimentismo, lulismo, precariado, novas classes médias...

\section{Considerações finais}

A importância do "novo sindicalismo" para o fim do regime militar e para o processo de redemocratização, bem como os seus desdobramentos na história recente do país, foi marcante nos estudos do trabalho no Brasil. Estes percorreram suas diversas fases, expressando ênfases e interpretações diversas. Algumas importantes lacunas, no entanto, podem ser evidenciadas.

Em um balanço de conjunto, é possível se constatar que as abordagens tiveram como foco o sindicalismo do $A B C$ paulista, em particular do setor metalúrgico, berço do "novo sindicalismo" e principal sustentáculo da construção do Sindicalismo CUT. Embora tenham sido produzidos alguns estudos sobre a trajetória da CUT em outras regiões do país - a exemplo de Medeiros, Silva, Véras de Oliveira, Ladosky, Costa, sobre os casos de Pernambuco, Piauí, Paraíba, Rio de Janeiro, Maranhão, respectivamente, ${ }^{71}$ entre outros -, tal não em dimensão suficiente para permitir uma visão mais ampla dessa experiência, considerando as especificidades regionais.

Do mesmo modo, a análise da experiência sindical brasileira das últimas quatro décadas não conseguiu produzir um esforço de pesquisa com o mesmo peso dado ao setor industrial e, mais em particular, ao segmento metalúrgico, não obstante iniciativas importantes sobre as experiências sindicais na área rural, ${ }^{72}$ no setor público, ${ }^{73}$ no ensino superior, ${ }^{74}$ no setor financeiro, ${ }^{75}$ nas telecomunicações ${ }^{76}$ etc.

Depois da eclosão do ciclo de greves operárias no final dos anos 1970 e início dos 80, vários contextos se estabeleceram, repercutindo na relação entre

70 SOUZA, Jessé. Ralé brasileira: quem é e como vive. Belo Horizonte: Editora UFMG, 2009; DINIZ, Eli. Depois do neoliberalismo: rediscutindo a relação Estado e desenvolvimento no novo milênio. Belo Horizonte: Humanitas, 2011; SINGER, André. Os sentidos do lulismo. São Paulo: Companhia das Letras, 2012; BRAGA, Ruy. A política do precariado: do populismo à hegemonia lulista. São Paulo: Boitempo, 2012 e POCHMANN, Marcio. Nova classe média? O trabalho na base da pirâmide social brasileira. São Paulo: Boitempo, 2012.

71 MEDEIROS, Rejane Pinto de. Cotidiano sindical: entraves e bandeiras. Recife. Dissertação (Mestrado em Sociologia), UFPE, 1992; SILVA, Roberto John Gonçalves da. A constituição do sujeito coletivo CUT-PI: institucionalização, prática e mudanças sócio-políticas. São Paulo. Dissertação (Mestrado em Serviço Social), PUC-SP, 1993; VÉRAS DE OLIVEIRA. A CUT somos nós...; LADOSKY, Mario Henrique. Movimento sindical e estratégia corporativista: a trajetória e os impasses da CUT no Rio de Janeiro. Rio de Janeiro. Dissertação (Mestrado em Sociologia), UFRJ, 1995; e COSTA, Cândida. Sindicalismo e cidadania: análise da relação entre CUT e Estado na construção da esfera pública no Brasil. São Paulo; São Luís: UNITRABALHO/ EDUFMA, 2000.

72 NOVAES, José Roberto. “Disputa sindical no campo: quem fica com a CONTAG?”. Tempo e Presença. Rio de Janeiro: CEDI, vol.13, n² 259, p.14-7, 1991; Idem. "Continuidades e rupturas no sindicalismo rural”. In: BOITO Jr. (org.). O sindicalismo brasileiro nos anos 80.

73 NOGUEIRA, Arnaldo. "Emergência e crise do Novo Sindicalismo no setor público brasileiro". In: JÁCOME RODRIGUES (org.). O novo sindicalismo vinte anos depois; Idem. A Liberdade Desfigurada - a Trajetória do Sindicalismo no Setor Público Brasileiro. São Paulo: Editora Expressão Popular, 2005 e SILVA, Sidney Jard. Companheiros servidores: o sindicalismo do setor público na CUT. Santo André: UFABC, 2013.

74 NAVARRO, Ignez Pinto. Andes - SN: um sindicato de intelectuais. Cuiabá: ADUFMAT, 2001.

75 BLASS, Leila Maria da Silva. Estamos em Greve! Imagens, gestos e palavras do movimento dos bancários. São Paulo: Hucitec, 1992.

76 CAVALCANTE. Sindicalismo e privatização das telecomunicações. 
sindicalismo e democracia no Brasil. Muito material de análise foi produzido a respeito. As transformações nas práticas sociais do trabalho e a permanente reinvenção das práticas sindicais seguiram suscitando esforços de pesquisa na área. Não se consumou a predição do "fim do trabalho", nem do "fim do sindicalismo".

Além de lacunas a serem preenchidas, como as indicadas acima, novas situações desafiam os pesquisadores sociais, suscitando novas releituras do passado. A propósito, ganhou relevância o fato de terem ocorrido, pela primeira vez nas últimas décadas, manifestações de massa (em junho de 2013) sem que tivessem sido protagonizadas pelos atores que se constituíram a partir da eclosão do "novo sindicalismo" e de seus desdobramentos. São estes indícios de "esgotamento" do ciclo iniciado naqueles acontecimentos de 1978/1980?

Recebido em: 02/03/2014

Aprovado em: 20/04/2014 